\title{
Life-history traits of batoids (Superorder Batoidea) in the Northeast Atlantic and the Mediterranean
}

\author{
Damian Villagra (D) Noemi Van Bogaert • Bart Ampe • Paddy Walker • \\ Sven Sebastian Uhlmann
}

Received: 13 March 2021 / Accepted: 4 December 2021 / Published online: 21 January 2022

(C) The Author(s) 2022

\begin{abstract}
Life-history traits provide a way to estimate the vulnerability of both individuals and populations of a species to disturbance (e.g., overexploitation, climate change). Life-history traits compilations for species of batoids in the Northeast Atlantic (NEA) and the Mediterranean Sea (MED) are scarce, outdated, and generally limited to a local or a regional scale. A literature review compiling values of 10 life-history traits describing the growth, reproductive and feeding strategies of 14 batoids in the NEA and the MED was performed. Via a principal components analysis (PCA) the main drivers of variance and (groups of) similar species were identified. Significant data gaps were revealed for natural mortality and lifespan, for most of the life-history traits of smalleyed (Raja microocellata), shagreen (Leucoraja
\end{abstract}

Supplementary Information The online version contains supplementary material available at https://doi.org/10.1007/ s11160-021-09695-3.

D. Villagra $(\bowtie) \cdot$ N. Van Bogaert .

B. Ampe $\cdot$ S. S. Uhlmann

ILVO: Instituut Voor Landbouw-Visserij en

Voedingsonderzoek, Ankerstraat 1, 8400 Ostend, Belgium

e-mail: dvillagrapetre@gmail.com

P. Walker

Dutch Elasmobranch Society, Mûnebuorren 25,

9132EJ Engwierum, Netherlands

S. S. Uhlmann

Marine Institute, Rinville, Co., Galway H91 R673, Ireland fullonica), and sandy (Leucoraja circularis) ray, and specifically for the English Channel and Bay of Biscay. The common skate complex (Dipturus batis complex) and white (Rostroraja alba) skate were found to be different from the rest of the species due to their larger sizes, relatively slow growth, and late maturity, which may make them more vulnerable to overexploitation, while the Raja spp. and Leucoraja spp. rays tend to be smaller species growing at faster rates. Growth and reproductive life-history should be considered as vulnerability to disturbance proxies, be used to update/establish management measures (i.e. minimum size) and enhance the stock assessment predictive ability (i.e. length based-indicators). Future research should be directed towards filling important regional data gaps and providing robust estimation for unreported parameters, such as natural mortality.

Keywords Plasticity - Growth - Reproduction · Fisheries · Management · Ray · Skates · Vulnerability · Strategy

\section{Introduction}

A comparative analysis of life-history traits of the Superorder Batoidea offers the opportunity for fisheries managers to take appropriate action to prevent their overfishing. The members of the Superorder Batoidea are widely distributed throughout the 
Northeast Atlantic Ocean (NEA) and the Mediterranean Sea (MED) (Ebert and Stehmann 2013; Last et al. 2016) and are being exploited by commercial fisheries as target and by-catch species. Generally recognized as K-selected species (MacArthur and Wilson 1967; Camhi et al. 1998), they are characterized by slow growth, late sexual maturity, low fecundity and long life (Hoenig and Gruber 1990), limiting their population's capacity to recover from overfishing (Camhi et al. 1998; ICES 2020a, b, c). To reduce the fisheries pressure on their populations, batoids have been temporarily exempted from the European Landing Obligation policy (Uhlmann et al. 2019; ICES 2020a, b, c), as they appear to have a high chance of survival after being discarded overboard at sea (e.g. Enever et al. 2009; Ellis et al. 2012; Catchpole et al. 2017). Conditional to this temporal exemption, the European Commission initiated a research trajectory called "Roadmap for rays and skates " (Commission of the European Union 2018) to increase current scientific knowledge, and fill data gaps concerning these species and their survivability. It is therefore of scientific importance to determine the state of the art of batoids research and data availability in the NEA, MED and to analyse the available data to provide useful outputs.

Currently, due to the limited data available on commercial fisheries, most batoids in the NEA and the MED are managed under a common Total Allowable Catch (TAC) and all stocks are assessed as datalimited (ICES 2012, 2020; Lart 2019), due to a lack of robust and long-term length-age data. Although, sampling and compiling such data for each species may be very complicated and/or costly, finding methods to distinguish and/or group species based on their vulnerability to fisheries and environmental changes and capacity to recover from overfishing would be of great value to increase the capacity to understand the true fishing pressure on each "group" of species, hence the quality of stock assessments and our capacity to ensure the sustainability of the fishing stocks.

Life-history traits vary widely between taxonomic and/or functional groups, based on species-specific adaptations and strategies to respond to prevailing environmental conditions (e.g. Walsh 1994). Functionally and taxonomically closely related species and even sub-populations of the same species can have significantly different life-history traits due to regional adaptations to environmental gradients (Fromentin and Fonteneau 2001; Félix et al. 2011), and/or due to different degrees of fishing pressure (Devine et al. 2012; Claireaux et al. 2018). Such variations can be used to understand the variability between and within species and to provide preliminary evidence for the adaptability to changes in the environment, such as climate change (Dalgleish et al. 2010), habitat degradation (Öckinger et al. 2010), and overfishing (Hoenig and Gruber 1990; Cortés et al. 2010; Patrick et al. 2010; Hobday et al. 2011). These features make lifehistory traits useful proxies for estimating the tolerance of a species to natural and/or anthropogenic disturbances, and they could be used to identify common life strategies among groups of species (Félix et al. 2011; Pecuchet et al. 2017).

As far as batoids in the NEA and the MED are concerned, studies of life-history traits usually report values for a limited number of traits for a single or a few species based on data from samples collected on a restricted regional scale (e.g. Du Buit 1977; Nottage and Perkins 1983; Ryland and Ajayi 1984; Brander and Palmer 1985). Interspecific (e.g., Gallagher et al. 2005) and/or interregional (e.g., McCully et al. 2012) analyses of batoids are scarce and outdated, but what is known about them was included within a recent synopsis (Last et al. 2016). Reviews and metaanalyses of fish taxa such as mackerel, tuna, and bonitos (Scombridae) (Juan-Jordá et al. 2013), flatfish (Pleuronectidae) (Félix et al. 2011), and multi-species analyses (Rochet 2000; King and McFarlane 2003; Frédou et al. 2016) resulted in the delineation of clusters of species with similar life-history strategies. Although batoids are generally identified as a K-selected species (Camhi et al. 1998), this probably oversimplifies the variety of adaptations exhibited in the wild (Nichols et al. 1976; Bielby et al. 2007). Lifehistory traits can be used to identify similar species or groups of species with higher vulnerability (e.g., late maturity and slow growth) at an individual (e.g., discard survival) and a population level (e.g., overfishing, climate change) and establish spatial-temporal management measures accordingly (i.e., TAC, maximum allowed by-catch, gear ban, gear selectivity, spatiotemporal avoidance). For instance, based on the life-history traits values of a species and/or groups of species, these could be identified as more likely/ unlikely to die after being discarded back at sea. These could ultimately provide proxies and/or be used to 
tune discard survival estimation, to be used and accounted for stock assessments for elasmobranchs in the future.

Considering the above, this study aimed to investigate inter-and intraspecific patterns in life-history traits of skate and other batoid species in the NEA and the MED through a literature review. Via principal component analysis (PCA) of the compiled lifehistory traits, species, and/or groups of species to which specific management strategies could be recommended due to their similar life-history strategies were identified. Furthermore, the compiled traits were then summarized by region of origin of the studies to analyse the plasticity of the traits across the distribution range of a species. Finally, both the compilation of available information on life-history traits and the detection of data gaps is essential for prioritizing future research efforts on batoids in the NEA and the MED.

\section{Materials and methods}

\section{Literature review}

A literature review (Khan et al., 2003; Pascual et al. 2017; Fennell et al. 2021) was conducted to identify life-history trait published values for batoids in the NEA and MED. First, the literature was screened to identify commonly reported life-history traits parameters for 14 batoids species: 11 skates (Rajidae) and 3 rays (Torpedinidae and Dasyatidae) in the NEA and the MED (Table 1). Batoid species of interest included: Starry ray (Amblyraja radiata); Common skate complex (Dipturus batis complex); Sandy ray (Leucoraja circularis), Shagreen ray (Leucoraja fullonica); Cuckoo ray (Leucoraja naevus); Blonde ray (Raja brachyura); Thornback ray (Raja clavata); Small-eyed ray (Raja microocellata); Spotted ray (Raja montagui); Undulate ray (Raja undulata); White skate (Rostroraja alba); Electric ray (Tetronarce nobiliana); Marbled electric ray (Torpedo marmorata); and Common stingray (Dasyatis pastinaca). From this first screening, a total of ten quantitative life-history parameters describing growth, reproduction and feeding habits of batoids in the NEA and MED were identified (Table 2).

Next, the Web of Science (WoS), Scopus and Google scholar databases were screened for relevant published values, using combinations of species- and trait-specific search terms for each of the identified life-history trait parameter identified previously. The scientific and common names (e.g., Raja clavata AND thornback ray), followed by combinations of keywords and derivatives related to each of the identified life-history traits (Table 2) were one by one used to identify published life-history trait values. Grey literature sources, such as species catalogues (e.g., Ebert and Stehmann 2013; Froese and Pauly 2019), and reports from the ICES Working Group for Elasmobranch Fishes (WGEF), were also consulted. Finally, the references list of the identified publications (i.e. papers, books, reports, etc.) were screened identify relevant peer-reviewed publications not included until this moment (Khan et al. 2003; Pascual et al. 2017; Fennell et al. 2021). Publications were excluded from the study based on the type of publication, geographic location of the study and whether the study has been cited in others. Only original research and other review paper were considered, while opinion and editorial publications were discarded. Values reported for a species were only included in our data base if the study was performed in the NEA and MED. All obtained values were compiled in a unique data base, together with information on the geographical location in which the study was performed, species and sex of the individuals analysed. The location was defined based on FAO major fishing areas of the Northeast Atlantic and Mediterranean Sea (FAO 2021). Values that could not be linked to a specific region/sub-region were defined as "Global", and were compiled in the Supplementary Table 1, but were not included in the data analysis. Wherever possible, separate values were recorded for sex. When this was impossible, the same value was assigned to both males and females.

Growth traits were described by the length at infinity $\left(\mathrm{L}_{\infty}\right)$, and growth rate $(\mathrm{K})$ (Table 2 ) parameters from the von Bertalanffy growth model (von Bertalanffy 1938). Both parameters have been widely published in the scientific fisheries literature and are being used in age-structured models. For elasmobranchs these parameters are not used the stock assessment due to data limitations and biological characteristics, but are key for these more robust assessment methods. Additionally, the lifespan of the species corresponds to the estimated maximum expected age. Natural mortality, was defined as the 
Table 1 Common, scientific, and three-letter identifier codes (FAO 2021) of batoids (Batoidea) of the Northeast Atlantic Ocean and the Mediterranean Sea were analysed in the literature review

\begin{tabular}{llll}
\hline Family & Common name & Species & FAO code \\
\hline Rajidae & Starry ray & Amblyraja radiata & RJR \\
& Common skate complex & Dipturus batis complex & RJB \\
& Sandy ray & Leucoraja circularis & RJI \\
& Shagreen ray & Leucoraja fullonica & RJF \\
& Cuckoo ray & Leucoraja naevus & RJN \\
& Blonde ray & Raja brachyura & RJH \\
& Thornback ray & Raja clavata & RJC \\
& Small-eyed ray & Raja microocellata & RJE \\
& Spotted ray & Raja montagui & RJM \\
& Undulate ray & Raja undulata & RJU \\
& White skate & Rostroraja alba & RJA \\
Torpedinidae & Electric ray & Tetronarce nobiliana & TTO \\
& Marbled electric ray & Torpedo marmorata & TTR \\
Dasyatidae & Common stingray & Dasyatis pastinaca & JDP \\
\hline
\end{tabular}

natural (i.e., predation, disease, and old age) loss rate of the population.

In fisheries science, the age $\left(\mathrm{Age}_{\mathrm{m}}\right)$ and length at maturity $\left(\mathrm{L}_{\mathrm{m}}\right)$ (Table 2 ) are commonly estimated from logistic regression between the size and the maturity states (mature/immature), providing estimates of ages and sizes at which $50 \%$ of the individuals of a species are sexually mature (Schnute and Richards 1990; Chen et al. 1994). Although maturation is a continuous process and achieved through a series of transitional states (e.g., range of values), age and length at maturity are point estimates for describing the species' reproductive traits. These parameters have been published for most skate and batoid species. However, because their estimation relies on dissections of a sufficiently large number (e.g., $>10^{3}$ ) of individuals, they may be of limited value for species caught in small amounts and/or subject to misidentification, such as small-eyed (Raja microocellata), shagreen (Leucoraja fullonica) and sandy (Leucoraja circularis) ray (McCully and Walls 2015; ICES 2020a, b, c). Furthermore, in contrast to bony fishes, ageing elasmobranchs commonly requires the analysis of vertebral sections and images techniques (Campana 2014; SUMARiS 2019). It is a still evolving discipline, meaning that a large proportion of the methods used in the past and their associated products (peer reviewed papers), may now be completely obsolete (Campana 2014). Fecundity data were also compiled and defined as the average total number of offspring (eggs or pups) produced per year per female. Development was defined as the time needed for the young to fully develop inside an egg or its mother's uterus. Regional fecundity and development data are usually limited to particular studies and/ or reports and are therefore commonly generalized for a species across its distribution. Differences in reproduction types were analyzed by categorizing the species as either oviparous (producing eggs) or viviparous (producing living young). The trophic level derived from FishBase (Froese and Pauly 2019) was used to describe the feeding strategy of each species.

\section{Exploratory analysis}

\section{Interspecific analysis}

We analysed the possibility of grouping and dividing the 14 batoid species based on their life-history traits values. A summarized data set was obtained by taking the mean value for each life-history trait parameter for each of the 14 batoid species, and for each sex, from all studies from the NEA and the MED. Correlation between continuous life-history parameters was first explored using the Spearman correlation index, using the corr \{stats\}, and plotted using the corrplot \{corrplot\} (Wie and Simko 2017) functions. The summarized data set was used to analyze the interspecific pattern of life-history traits through a principal component analysis (PCA), using the function "prcomp" \{ stats To perform the PCA, five species: common stingray (Dasyatis pastinaca), electric 
Table 2 List of life-history traits and associated search terms that were used to screen published primary literature for lifehistory trait values of batoid skate species. Each combination is preceded by the combination of the common and the scientific name of each species (see Table 1)

\begin{tabular}{|c|c|c|c|}
\hline Parameter & Acronym & Search terms & Definition \\
\hline Growth rate (/year) & $\mathrm{K}$ & $\begin{array}{l}\ldots \text { AND Growth rate AND } \\
\text { Infinity AND Bertalanffy }\end{array}$ & Rate of approach to asymptotic size \\
\hline Length at infinity $(\mathrm{cm})$ & $\begin{array}{l}\mathrm{L}_{\text {inf }} \text { or } \\
\mathrm{L}_{\infty}\end{array}$ & $\begin{array}{l}\ldots \text { AND Length AND Infinity } \\
\text { AND Bertalanffy }\end{array}$ & $\begin{array}{l}\text { Asymptotic length based on the von Bertalanffy } \\
\text { growth model }\end{array}$ \\
\hline Lifespan (years) & Lifespan & ... AND Lifespan & Estimated maximum age \\
\hline Natural mortality & M & ... AND Natural mortality & The ratio of death by natural causes \\
\hline Development (months) & Develop & ... AND Development & $\begin{array}{l}\text { The time needed for the young to fully develop in an } \\
\text { egg or their mother's uterus }\end{array}$ \\
\hline Age at maturity (years) & $\mathrm{Age}_{\mathrm{m}}$ & ... AND Age AND Maturity & $\begin{array}{l}\text { Age at which } 50 \% \text { of individuals have reached sexual } \\
\text { maturity }\end{array}$ \\
\hline Length at maturity $(\mathrm{cm})$ & $\mathrm{L}_{\mathrm{m}}$ & ... AND Length AND Maturity & $\begin{array}{l}\text { Length at which } 50 \% \text { of individuals have reached } \\
\text { sexual maturity }\end{array}$ \\
\hline $\begin{array}{l}\text { Fecundity (eggs/pups per } \\
\text { female per year) }\end{array}$ & $\mathrm{Fec}$ & $\begin{array}{l}\ldots \text { AND Fecundity AND (eggs } \\
\text { OR pups) }\end{array}$ & Number of offspring produced per year per female \\
\hline Reproduction type & RT & $\begin{array}{l}\text {... AND (Oviparous OR } \\
\text { Viviparous) }\end{array}$ & $\begin{array}{l}\text { Whether the species produce eggs (oviparous) or living } \\
\text { developed young (viviparous) }\end{array}$ \\
\hline Trophic level & TL & - & Mean value reported by FishBase \\
\hline
\end{tabular}

(Tetronarce nobiliana), sandy, shagreen and smalleyed ray; were removed from the summarized data set because of the absence of published values for age at maturity $\left(\mathrm{Age}_{\mathrm{m}}\right)$. Similarly, the natural mortality and lifespan were not included in the analysis as values for these parameters were available for only three and five of the analyzed species respectively. The remaining seven continuous life-history traits $\left(\mathrm{Age}_{\mathrm{m}}, \mathrm{L}_{\mathrm{m}}, \mathrm{L}_{\infty}, \mathrm{K}\right.$, Development, Fecundity, and Trophic level) of nine batoid species were then used to perform the PCA. Additionally, clustering patterns between batoid species were explored using the Euclidean distance, and three different linkage clustering methods (complete, single and average), using the "dist" \{stats\}, "hclust" \{stats\}, "cutree" \{stats\}, and "ggdendrogram" \{ggdendro\} (De Vries and Ripley 2020) functions. The three clustering methods differ in the distance between clusters is calculated. Single linkage merges the two clusters whose two closest members have the smallest distance, while complete linkage merges the two clusters whose merger has the smallest distance. Finally, the average linkage represents an intermediate method which takes the average distance between the members of two clusters.

\section{Intraspecific analysis}

We aimed to analyse the intraspecific variation of the life-history traits of the 14 batoid species by summarizing the compiled data per geographical region of origin of each study using PCA. Two geographical regions were defined. The North East Atlantic (NEA) region, including the: Skagerrak, North Sea, English Channel, Celtic Sea, Bay of Biscay and the Portuguese waters sub-regions, and the Mediterranean and Black Sea region (MED), including the Mediterranean Sea and the Black Sea sub-regions (Fig. 1). The lack of regional data for most species and life-history traits, impeded to perform the analysis as planned. For instance, values for at least two different sub-regions were obtained for only six (starry, Amblyraja radiata; cuckoo, Leucoraja naevus; blonde, Raja brachyura; thornback, Raja clavata; spotted, Raja montagui; and undulate, Raja undulata) of the 14 analysed species and for only four (age at maturity, length at maturity, length at infinity, and growth rate) of the 10 lifehistory traits. Therefore values from different regions and sub-regions for each of the six species were compared by comparing the average and standard deviation of the reported values for each parameter in each sub-region/region. 


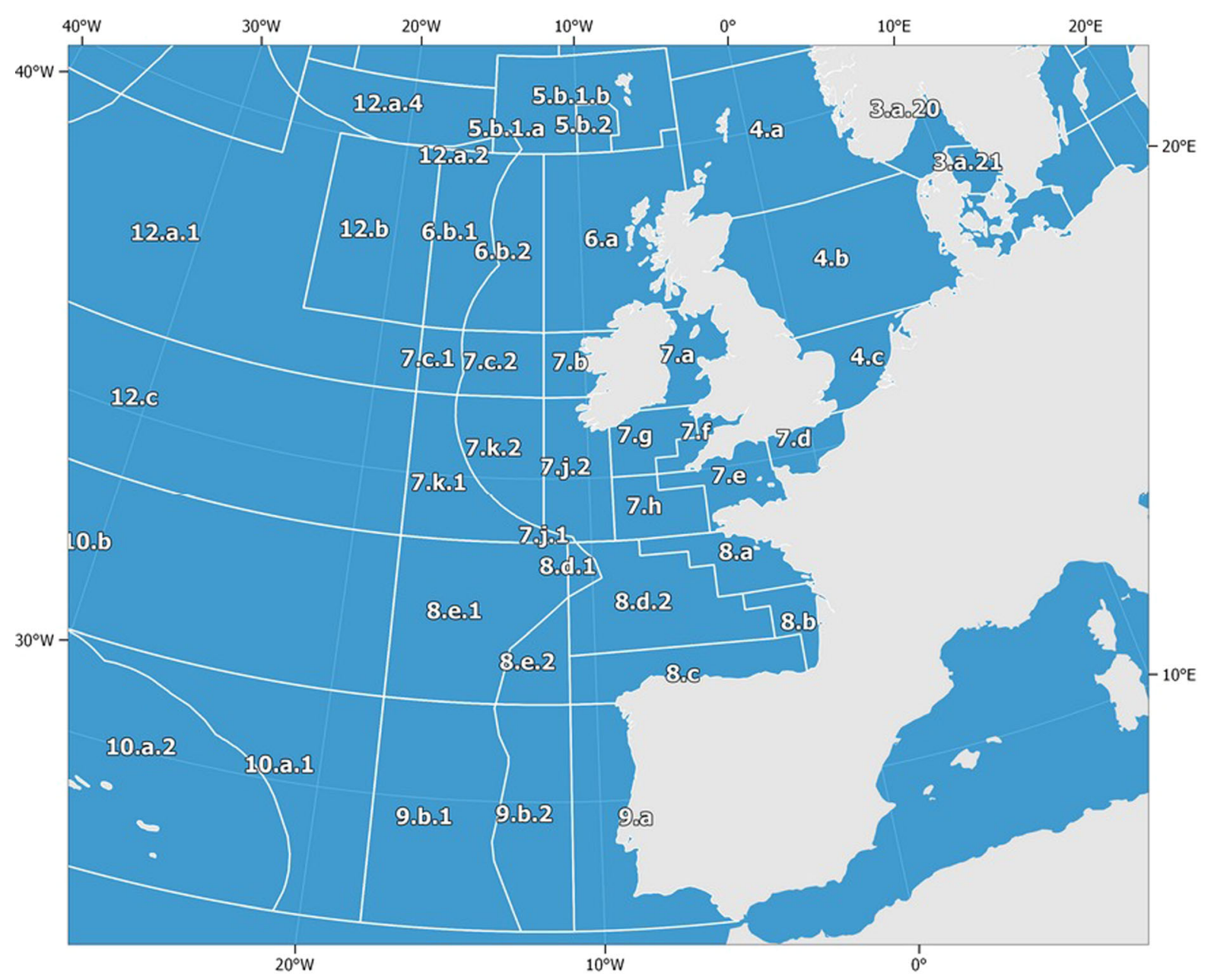

Fig. 1 FAO major fishing areas of the Northeast Atlantic. Skagerrak and Kattegat (3.a), North Sea (4.a-c), Celtic Sea (7.g-h), English Channel (7.d-7.e), Bay of Biscay (8.a-c), Portuguese Waters (9.a-b) and Mediterranean Sea. C FAO 1990-2021

All analysis and plotting were performed in $\mathrm{R}$ statistical software version 4.0.2 (R Core Team 2020).

\section{Results}

Systematic literature review

The full data set of compiled life-history traits and all associated references can be accessed in Supplementary Table 1 and Supplementary Table 2, respectively. The origin of the studies varied with the species analysed following their natural distribution (Fig. 2). Life-history traits of batoids from the genera Dipturus, Raja, and Leucoraja were mainly reported for NEA waters (e.g., North Sea, British Isles, Celtic/Irish Sea, amongst others), whereas life-history traits for more southernly distributed species, such as the white skate, common stingray, electric and marbled electric (Torpedo marmorata) ray (e.g. Dulvy et al. 2006; Notarbartolo Di Sciara et al. 2009; Serena et al. 2009), were mainly studied in the MED (e.g., Balearic Island, Tunisian coast).

For certain life-history traits, the overview (Table 3) clearly shows where essential information is still lacking (e.g., absent values for natural mortality, lifespan and, to a lesser degree, age at maturity). Lifehistory traits for the thornback, blonde, undulate and spotted ray have been commonly reported in the scientific literature, with studies encompassing 


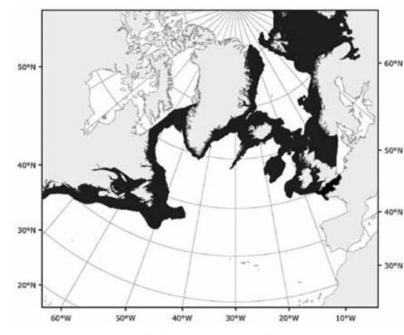

Amblyraja radiata

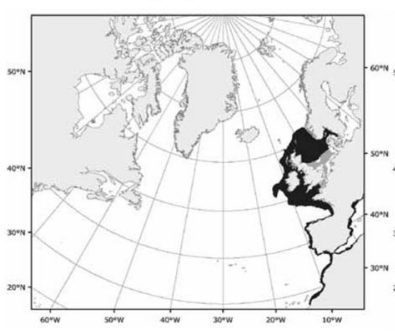

Leucoraja naevus

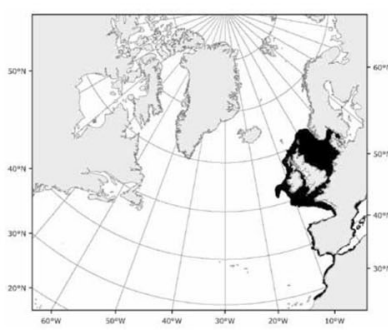

Raja montagui

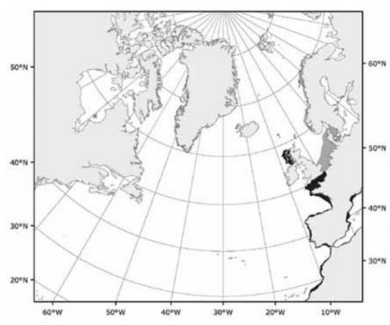

Torpedo marmorata

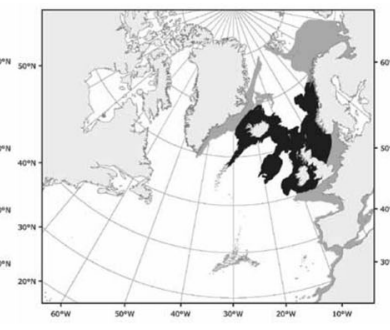

Dipturus batis complex

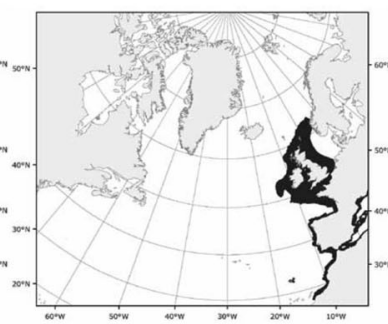

Raja brachyura

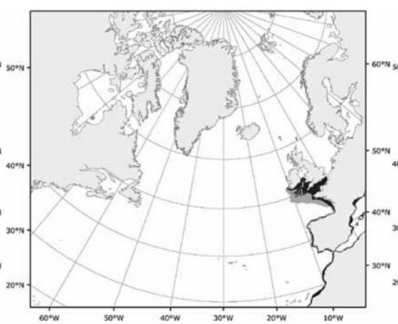

Raja undulata

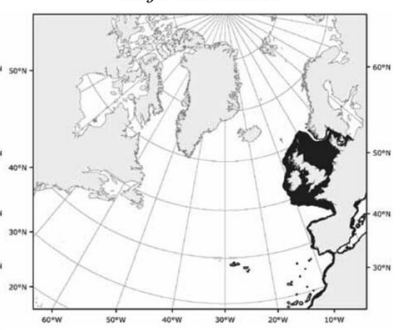

Dasyatis pastinaca

Fig. 2 Distribution of the starry ray (Amblyraja radiata), common/blue skate (Dipturus batis complex), sandy (Leucoraja circularis), shagreen (Leucoraja fullonica), cuckoo (Leucoraja naevus), blonde (Raja brachyura), thornback (Raja clavata),

different geographical sub-regions. Contrarily, values for rare and less abundant species, such as the sandy, shagreen, and small-eyed ray, are equally rare and limited, leaving important data gaps (Table 3).

Strong $(>0.5)$ Spearman correlation values were obtained between growth and maturity parameters (Fig. 3), because species with larger lengths at infinity

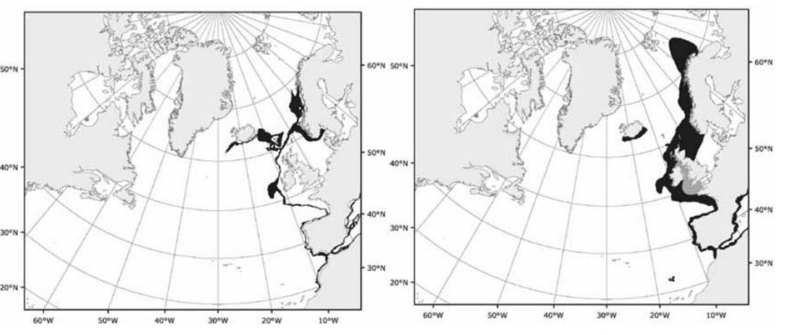

Leucoraja circularis

Leucoraja fullonica

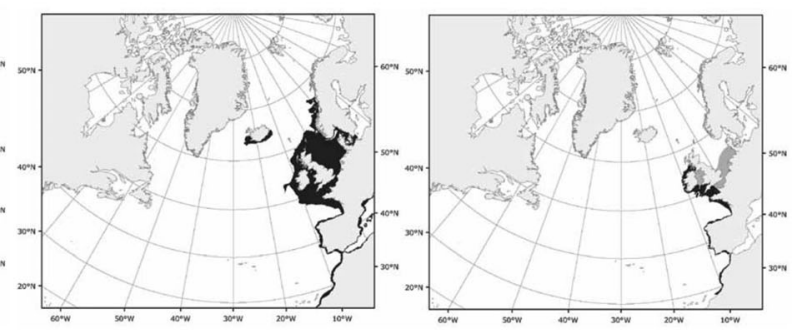

Raja microocellata

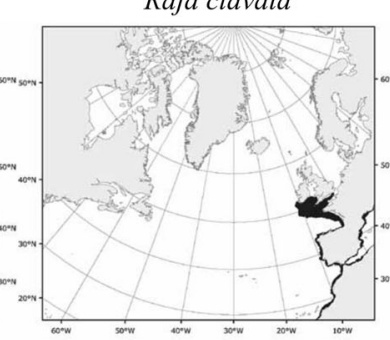

Rostroraja alba

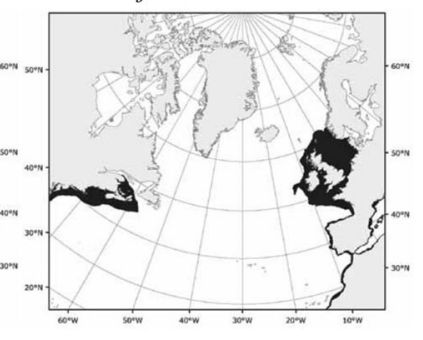

Tetronarce nobiliana small-eyed (Raja microocellata), spotted (Raja montagui), undulate ray (Raja undulata), white skate (Rostroraja alba), electric (Totronarce nobiliana), marbled electric ray (Torpedo

$\left(\mathrm{L}_{\infty}\right)$, take longer to mature $\left(\mathrm{Age}_{\mathrm{m}}\right)$, reaching larger sizes $\left(\mathrm{L}_{\mathrm{m}}\right)$ due to a slower growth rate $(\mathrm{K})$. The trophic level was found to be positively correlated to the development time, with higher trophic level species requiring more time to fully develop. Fecundity did not register a strong correlation with any of the other life-history traits analysed. 


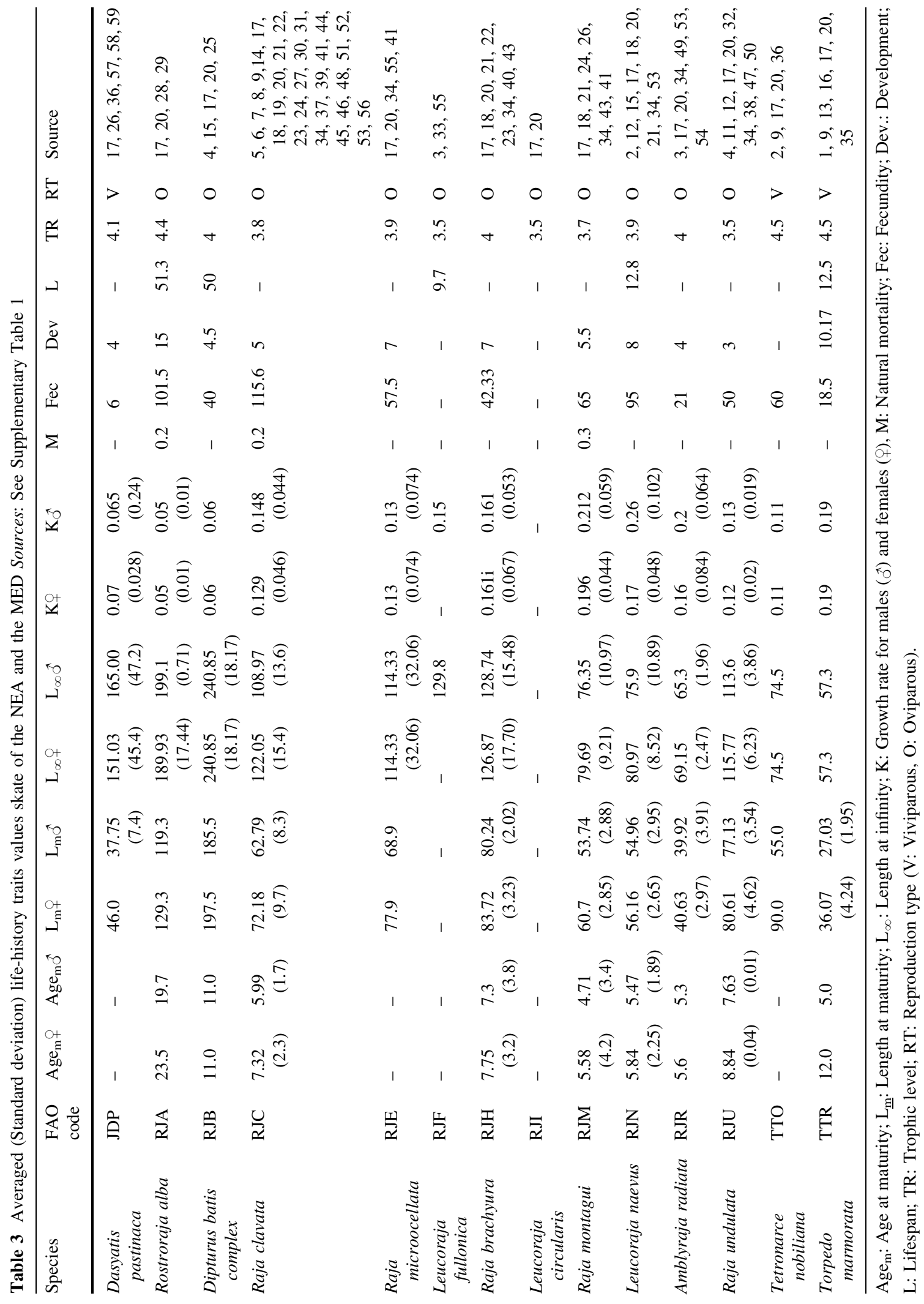




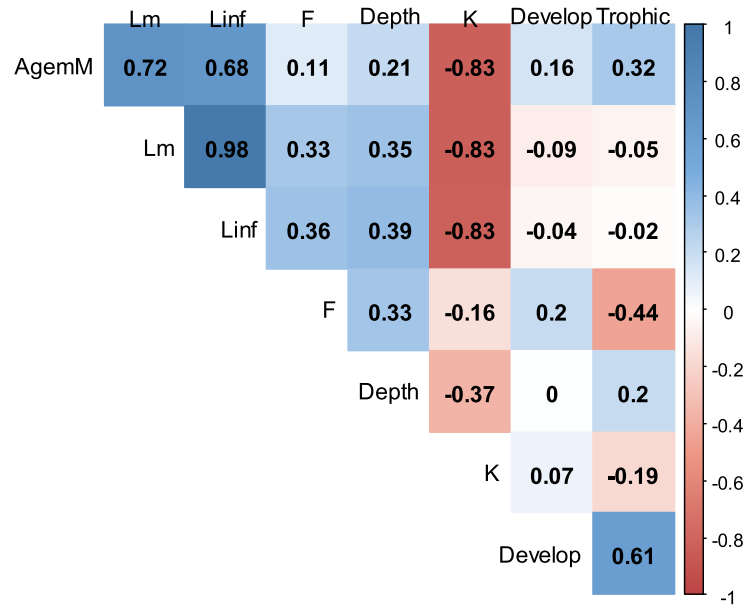

Fig. 3 Spearman correlation matrix (corrplot \{corrplot\}) for life-history traits of batoids and related species in the NEA and MED. Acronyms are detailed in Table 2. Direct $(0,1)$ and inverse $(0,-1)$ correlation, are represented with blue and red tones respectively

\section{Exploratory analyses}

\section{Interspecific analysis}

The first two principal components of the PCA explained $78.56 \%$ of the total variance contained within the mean of the nine life-history traits analysed of nine species of batoids (starry, thornback, blonde, spotted, undulate cuckoo and electric ray, white skate and common skate complex) (Fig. 4). Growth and reproductive life-history traits (i.e., age and length at maturity, length at infinity, and growth rate), were mainly related with the first PCA axis (52.63\% of total variation), and the trophic level and development by the second axis (25.93\% of total variation). Fecundity was largely related with the third PC only.

From this analysis two "groups" were distinguished. On one hand, the white skate and the common skate complex are considerably different from all other analyzed species, because of their very large sizes $\left(\mathrm{L}_{\infty}: 189.90-240.90 \mathrm{~cm} ; \quad \mathrm{L}_{\mathrm{m}}\right.$ : $119.30-197.50 \mathrm{~cm})$ and late maturation $\left(\mathrm{Age}_{\mathrm{m}}\right.$ : 11.00-23.4 years) due to a low growth rate (K:0.05-0.06 /year) (Table 3). However, these species could also be divided based on the second PCA axis, because they differ in their trophic level and time needed for the development of the young. White skate has the longest development time (15 months) of all analyzed species and one of the highest trophic levels (4.4), while the common skate complex's eggs develop relatively quickly (4 months) and adults are lower in the trophic web (4.0). All remaining species

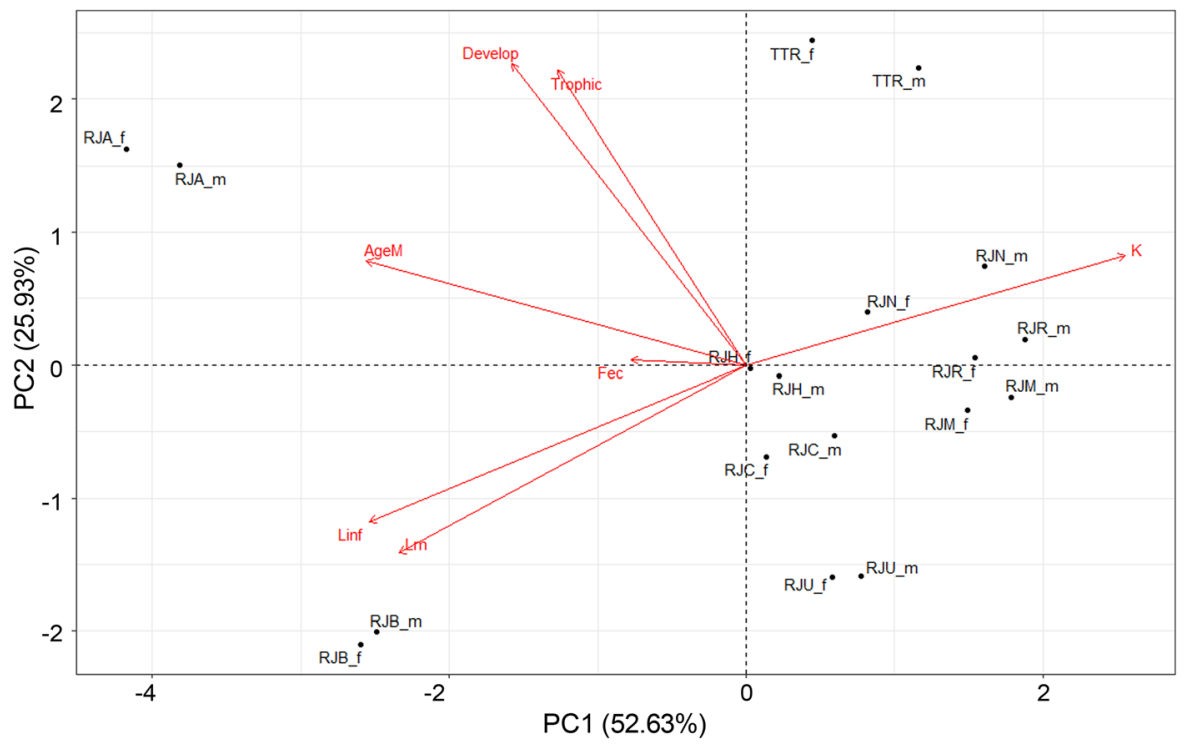

Fig. 4 Biplot of the two first principal components of the PCA of age at maturity (AgeM), length at maturity $\left(\mathrm{L}_{\mathrm{m}}\right)$, length at infinity $\left(\mathrm{L}_{\mathrm{inf}}\right)$, growth rate, $(\mathrm{K})$, Fecundity $(\mathrm{Fec})$, development (Develop) and trophic level (Trophic), of male (_m) and female (_f) blonde (RJH), cuckoo (RJN), spotted (RJM), thornback (RJC) and undulate (RJU) and marbled electric (TTR) rays, common skate complex (RJB), starry (RJR) and white skate (RJA) in the NEA and MED 


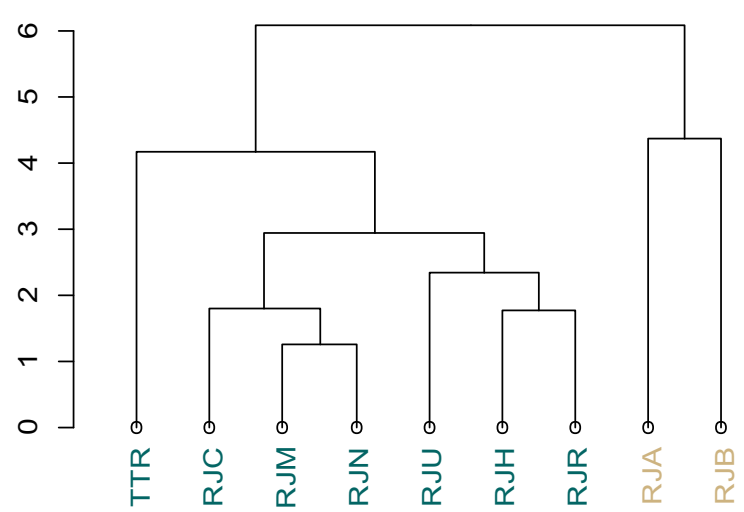

Fig. 5 Cluster (complete linkage) plot of the Euclidean distance of age at maturity $\left(\mathrm{Age}_{\mathrm{m}}\right)$, length at maturity $\left(\mathrm{L}_{\mathrm{m}}\right)$, length at infinity ( $\mathrm{L}_{\text {inf }}$ ), growth rate, $(\mathrm{K})$, Fecundity $(\mathrm{Fec})$, development (Develop) and trophic level (Trophic) of blonde (RJH), cuckoo (RJN), spotted (RJM), thornback (RJC) and undulate (RJU) and marbled electric (TTR) rays, common skate complex (RJB), thorny (RJR) and white skate (RJA)

appear to be clustered together by their smaller sizes $\left(\mathrm{L}_{\infty}: 57.3-126.9 \mathrm{~cm}\right)$ and faster growth (K: $0.12-0.26 /$ year), reaching maturity at younger ages (Age $\mathrm{m}_{\mathrm{m}}$ :4.7-8.8) and smaller sizes $\left(\mathrm{L}_{\mathrm{m}}: 27.0-83.7 \mathrm{~cm}\right)$. Nevertheless, based on the second PCA axis, two species stood out from this group: the marbled electric ray, for its long development time (10 months) and high trophic level (4.5), and at the opposite side of this axis, the undulate ray, with one of the shortest development times (3 months) and trophic levels (3.5). Similarly, the cluster analysis (Fig. 5) clearly shows the presence of at least two distinct groups of species, with, on one hand, the white skate and the common skate complex and on the other hand, the seven remaining species. In the latter group, the marbled electric ray was identified as the most different species. The described grouping pattern did not change significantly regarding the three different linkage clustering methods used (single, complete, and average linkage).

\section{Intraspecific analysis}

The intraspecific analysis of life-history traits between different geographical regions was severely limited by the lack of available data for most species and most life-history traits (Supplementary Table 1 and Fig. 1). A summary of the available life-history traits studies per sub-region and species is presented in Supplementary Table 3. Although, their distribution generally encompasses more than one sub-region, no comparison between sub-regions and/or regions was

Table 4 Cross-study average (standard deviation) life-history trait values for thornback ray (Raja clavata) in different geographic regions (Northeast Atlantic and Mediterranean and Black Sea) and sub-regions (North Sea, Celtic Sea, English Channel, Bay of Biscay, Portuguese waters, Mediterranean, and Black Sea) Sources: See Supplementary Table 1

\begin{tabular}{|c|c|c|c|c|c|c|c|c|c|}
\hline Region/sub-regions & $\mathrm{Age}_{\mathrm{m}+}$ & $\mathrm{Age}_{\mathrm{m}} \widehat{\widehat{T}}$ & $\mathrm{~L}_{\mathrm{m}+}+$ & $\mathrm{L}_{\mathrm{m}} \hat{\jmath}$ & $\mathrm{L}_{\infty}$ 우 & $\mathrm{L}_{\infty} \hat{\jmath}$ & $\mathrm{K}_{+}$ & $\mathrm{K} \widehat{\partial}$ & Source \\
\hline Northeast Atlantic & $\begin{array}{l}6.73 \\
(1.81)\end{array}$ & $\begin{array}{l}5.7 \\
(1.63)\end{array}$ & $\begin{array}{l}73.10 \\
(9.83)\end{array}$ & $\begin{array}{r}64.24 \\
\quad(7.02)\end{array}$ & $\begin{array}{c}122.32 \\
(16.64)\end{array}$ & $\begin{array}{l}109.01 \\
\quad(14.46)\end{array}$ & $\begin{array}{l}0.133 \\
(0.05)\end{array}$ & $\begin{array}{l}0.154 \\
(0.045)\end{array}$ & - \\
\hline North Sea & 8.8 & 7.1 & $\begin{array}{l}74.04 \\
(6.29)\end{array}$ & $\begin{array}{l}67.4 \\
\quad(0.74)\end{array}$ & $\begin{array}{l}103.3 \\
\quad(20.74)\end{array}$ & $93.3(6.6)$ & $\begin{array}{l}0.18 \\
\quad(0.06)\end{array}$ & $0.2(0.04)$ & $33,37,54$ \\
\hline Celtic Seas & $\begin{array}{l}5.7 \\
(0.58)\end{array}$ & $5(1.58)$ & $\begin{array}{l}70.1 \\
(4.40)\end{array}$ & $\begin{array}{l}61.5 \\
(3.01)\end{array}$ & $\begin{array}{l}122.9 \\
(15.13)\end{array}$ & $\begin{array}{l}108.7 \\
\quad(15.33)\end{array}$ & $\begin{array}{l}0.13 \\
(0.05)\end{array}$ & $\begin{array}{l}0.15 \\
(0.05)\end{array}$ & $\begin{array}{c}5,18,19,21,23 \\
33,39,41,56\end{array}$ \\
\hline English Channel & - & - & $\begin{array}{l}86.7 \\
(8.06)\end{array}$ & $72(0.99)$ & - & - & - & - & 51,52 \\
\hline Bay of Biscay & - & - & - & - & - & - & - & - & - \\
\hline Portuguese waters & - & - & 78.4 & 67.6 & $\begin{array}{r}133.9 \\
(5.89)\end{array}$ & $120(2.54)$ & $\begin{array}{l}0.1 \\
\quad(0.001)\end{array}$ & $\begin{array}{l}0.12 \\
\quad(0.018)\end{array}$ & $43,45,46$ \\
\hline $\begin{array}{l}\text { Mediterranean and } \\
\text { Black Sea }\end{array}$ & $\begin{array}{l}8.1 \\
(1.55)\end{array}$ & $\begin{array}{l}5.7 \\
\quad(0.49)\end{array}$ & $\begin{array}{l}71.13 \\
(10.67)\end{array}$ & $\begin{array}{l}59.69 \\
(10.10)\end{array}$ & $\begin{array}{r}120.55 \\
(8.41)\end{array}$ & $\begin{array}{r}108.75 \\
(11.24)\end{array}$ & $\begin{array}{l}0.108 \\
\quad(0.003)\end{array}$ & $\begin{array}{l}0.119 \\
(0.029)\end{array}$ & - \\
\hline Mediterranean & $\begin{array}{l}8.1 \\
(1.55)\end{array}$ & $\begin{array}{l}5.7 \\
(0.49)\end{array}$ & $\begin{array}{l}71.87 \\
(11.49)\end{array}$ & $59(10.86)$ & $\begin{array}{r}120.6 \\
(8.41)\end{array}$ & $\begin{array}{l}108.8 \\
(11.24)\end{array}$ & $\begin{array}{l}0.11 \\
\quad(0.003)\end{array}$ & $\begin{array}{l}0.12 \\
(0.03)\end{array}$ & $7,8,10,27,20,48$ \\
\hline Black Sea & - & - & 66.7 & 64.0 & - & - & & & 14 \\
\hline
\end{tabular}

Values in bold represent the mean value for the region. Age $\mathrm{m}_{\mathrm{m}}$ : Age at maturity; $\mathrm{L}_{\mathrm{m}}$ : Length at maturity; $\mathrm{L}_{\infty}$ : Length at infinity; $\mathrm{K}$ : Growth rate for males (ふ̋) and females (ㅇ). 
Table 5 Cross-study average (standard deviation) life-history trait values for blonde ray (Raja brachyura) in different geographic regions (Northeast Atlantic and Mediterranean and
Black Sea) and sub-regions (North Sea, Celtic Sea, English Channel, Bay of Biscay, Portuguese waters and Mediterranean Sea) Sources: See Supplementary Table 1

\begin{tabular}{|c|c|c|c|c|c|c|c|c|c|}
\hline Region/sub-regions & $\operatorname{Age}_{\mathrm{m}}+$ & $\operatorname{Age}_{\mathrm{m}} \hat{\widehat{\theta}}$ & $\mathrm{L}_{\mathrm{m}+}+$ & $\mathrm{L}_{\mathrm{m}} \hat{\sigma}$ & $\mathrm{L}_{\infty}$ + & $\mathrm{L}_{\infty} \hat{0}^{-}$ & $\mathrm{K}_{+}$ & $\mathrm{K} \hat{\jmath}$ & Source \\
\hline Northeast Atlantic & 5.5 & 4.6 & $\begin{array}{l}83.5 \\
(0.13)\end{array}$ & $\begin{array}{l}80 \\
\quad(2.77)\end{array}$ & $\begin{array}{l}130.8 \\
(17.75)\end{array}$ & $\begin{array}{r}133.728 \\
(12.41)\end{array}$ & $\begin{array}{l}0.176 \\
(0.067)\end{array}$ & $\begin{array}{l}0.19 \\
\quad(0.052)\end{array}$ & - \\
\hline North/Celtic Sea & - & - & 83.4 & 78 & - & - & - & - & 34 \\
\hline Celtic Sea & 5.5 & 4.6 & 83.6 & 81.9 & $\begin{array}{l}129.9 \\
(21.62)\end{array}$ & $\begin{array}{l}133.8 \\
(15.20)\end{array}$ & $\begin{array}{l}0.19 \\
\quad(0.068)\end{array}$ & $\begin{array}{l}0.19 \\
\quad(0.047)\end{array}$ & $18,21,23$ \\
\hline English Channel & - & - & - & - & - & - & - & - & - \\
\hline Bay of Biscay & - & - & - & - & - & - & - & - & - \\
\hline Portuguese waters & - & - & - & - & 133.5 & 133.5 & 0.12 & 0.12 & 43 \\
\hline $\begin{array}{l}\text { Mediterranean and } \\
\text { Black Sea }\end{array}$ & 14 & 10 & 87.9 & 80.8 & 111.14 & 108.81 & 0.1 & 0.11 & - \\
\hline Mediterranean & 14 & 10 & 87.9 & 80.8 & 111.14 & 108.81 & 0.1 & 0.11 & 40 \\
\hline
\end{tabular}

Values in bold represent the mean value for the region. Age $\mathrm{m}_{\mathrm{m}}$ Age at maturity; $\mathrm{L}_{\mathrm{m}}$ : Length at maturity; $\mathrm{L}_{\infty}$ : Length at infinity; K: Growth rate for males (ふ) and females (ㅇ).

Table 6 Cross-study average (standard deviation) life-history trait values for spotted ray (Raja montagui) in different geographic regions (Northeast Atlantic and Mediterranean and
Black Sea) and sub-regions (North Sea, Celtic Sea, English Channel, Bay of Biscay and Portuguese waters) Sources: See Supplementary Table 1

\begin{tabular}{|c|c|c|c|c|c|c|c|c|c|}
\hline Region/sub-regions & $\mathrm{Age}_{\mathrm{m}+}$ & $\mathrm{Age}_{\mathrm{m}} \hat{\sigma}$ & $\mathrm{L}_{\mathrm{m}+}$ & $\mathrm{L}_{\mathrm{m}} \hat{\sigma}$ & $\mathrm{L}_{\infty}$ ㅇ & $\mathrm{L}_{\infty} \hat{0}$ & $\mathrm{~K}_{+}$ & $\mathrm{K} \hat{\jmath}$ & Source \\
\hline Northeast Atlantic & $\begin{array}{l}5.6 \\
(2.04)\end{array}$ & $\begin{array}{l}4.7 \\
1.83)\end{array}$ & $\begin{array}{l}60.7 \\
(2.82)\end{array}$ & $\begin{array}{l}53.7 \\
(2.88)\end{array}$ & $\begin{array}{l}79.6 \\
(9.20)\end{array}$ & $\begin{array}{r}76.35 \\
(10.97)\end{array}$ & $\begin{array}{l}0.196 \\
(0.044)\end{array}$ & $\begin{array}{l}0.213 \\
(0.058)\end{array}$ & \\
\hline North Sea & 7 & 6 & 62.2 & 56.7 & 79.2 & 75.1 & 0.21 & 0.19 & 54 \\
\hline North/Celtic Sea & - & - & 62.5 & 50.9 & - & - & - & - & 34 \\
\hline Celtic Sea & 4.1 & 3.4 & 57.4 & 53.7 & $\begin{array}{l}80.8 \\
\quad(11.61)\end{array}$ & $\begin{array}{l}76.8 \\
\quad(14.14)\end{array}$ & $\begin{array}{l}0.18 \\
\quad(0.05)\end{array}$ & $\begin{array}{l}0.21 \\
\quad(0.083)\end{array}$ & $18,21,23,41$ \\
\hline English Channel & - & - & - & - & - & - & - & - & - \\
\hline Bay of Biscay & - & - & - & - & - & - & - & - & - \\
\hline Portuguese waters & - & - & - & - & 75.9 & 75.9 & 0.23 & 0.23 & 43 \\
\hline $\begin{array}{l}\text { Mediterranean and } \\
\text { Black Sea }\end{array}$ & - & - & - & - & - & - & - & - & - \\
\hline
\end{tabular}

Values in bold represent the mean value for the region. $\mathrm{Age}_{\mathrm{m}}$ : Age at maturity; $\mathrm{L}_{\mathrm{m}}$ : Length at maturity; $\mathrm{L}_{\infty}$ : Length at infinity; $\mathrm{K}$ : Growth rate for males $(\hat{\delta})$ and females $(+)$.

possible for the common skate, sandy, shagreen, small-eyed ray, white skate, electric and marbled electric ray and common stingray, due to the absence of studies in more than two regions. For example, the electric and common stingray distribute beyond the Mediterranean Sea (i.e. North Sea, Celtic Sea, English Channel and Bay of Biscay), but no studies reporting life-history trait values were found from other region/sub-regions. Similarly, common skate complex life-history traits' studies were only found for the
Celtic Sea, while the species can also be found in the North Sea (Supplementary Table 3).

Sufficient values to compare life-history traits from studies performed in the NEA and MED region were only available for the thornback and blonde ray (Tables 4 and 5). Reported values for the spotted and undulated ray covered several regions of the NEA, but did not included studies performed in the MED (Tables 6 and 7). Similarly, despite occurring from the North Sea to the Atlantic Iberian waters (ICES 2020b; 2020c), life-history trait values for the cuckoo 
Table 7 Cross-study average (standard deviation) life-history trait values for undulate ray (Raja undulata) in different geographic regions (Northeast Atlantic and Mediterranean and
Black Sea) and sub-regions (North Sea, Celtic Sea, English Channel, Bay of Biscay and Portuguese waters) Sources: See Supplementary Table 1

\begin{tabular}{|c|c|c|c|c|c|c|c|c|c|}
\hline Region/sub-regions & $\mathrm{Age}_{\mathrm{m}+}$ + & $\mathrm{Age}_{\mathrm{m}} \hat{\sigma}$ & $\mathrm{L}_{\mathrm{m}+}$ 品 & $\mathrm{L}_{\mathrm{m}} \hat{\sigma}$ & $\mathrm{L}_{\infty}$ ㅇ & $\mathrm{L}_{\infty} \hat{0}$ & $\mathrm{~K}_{+}$ & $\mathrm{K} \hat{\jmath}$ & Source \\
\hline Northeast Atlantic & $\begin{array}{l}8.8 \\
\quad(0.19)\end{array}$ & $\begin{array}{l}7.6 \\
(0.04)\end{array}$ & $\begin{array}{r}81.55 \\
(4.27)\end{array}$ & $\begin{array}{r}77.71 \\
(3.38)\end{array}$ & $\begin{array}{r}115.8 \\
(6.23)\end{array}$ & $\begin{array}{c}113.6 \\
(3.86)\end{array}$ & $\begin{array}{l}0.12 \\
\quad(0.02)\end{array}$ & $\begin{array}{l}0.13 \\
\quad(0.019)\end{array}$ & - \\
\hline North/Celtic Sea & - & - & 82.3 & - & - & - & - & - & 34 \\
\hline Celtic Sea & - & - & - & - & - & - & - & - & - \\
\hline English Channel & - & - & 83.1 & 78.4 & - & - & - & - & 50 \\
\hline Bay of Biscay & - & - & 83.8 & 81.2 & - & - & - & - & 50 \\
\hline Portuguese waters & $\begin{array}{l}8.8 \\
\quad(0.19)\end{array}$ & $\begin{array}{l}7.6 \\
(0.04)\end{array}$ & $\begin{array}{l}80.6 \\
\quad(5.17)\end{array}$ & $\begin{array}{l}75.5 \\
\quad(2.28)\end{array}$ & $\begin{array}{l}115.8 \\
(6.23)\end{array}$ & $\begin{array}{c}113.6 \\
(3.86)\end{array}$ & $\begin{array}{l}0.12 \\
\quad(0.02)\end{array}$ & $\begin{array}{l}0.13 \\
\quad(0.019)\end{array}$ & $7,11,12,38,47$ \\
\hline $\begin{array}{l}\text { Mediterranean and } \\
\text { Black Sea }\end{array}$ & - & - & - & - & - & - & - & - & - \\
\hline
\end{tabular}

Values in bold represent the mean value for the region. Age $\mathrm{m}_{\mathrm{m}}$ : Age at maturity; $\mathrm{L}_{\mathrm{m}}$ : Length at maturity; $\mathrm{L}_{\infty}$ : Length at infinity; $\mathrm{K}$ : Growth rate for males $(\hat{\jmath})$ and females $(+)$.

ray (Leucoraja naevus) had only been reported for the North and Celtic Sea (Table 8). Although, the so far mentioned species, could be identified as the most data abundant species, the studies from which life-history traits were obtained did not covered homogeneously their entire distribution. For instance, although all these species occur in the Bay of Biscay and English Channel, values for these sub-regions were reported only reported for two (thornback and blonde ray) and one (blonde ray) species respectively. Values for all life-history traits of the starry rays (Amblyraja radiata) were obtained for the North Sea and Skagerrak, while no reports for the English Channel and Celtic Sea, where this species also occurs were found (Table 9).

Thornback ray Both females and males thornback rays were found to in average mature at later ages in the North Sea, than in the Mediterranean Sea. However the strong deviation in age at maturity values in studies of the Mediterranean could mean that the values from both regions (i.e. NEA and MED) overlap. In the Celtic sea, female thornback rays matured at younger ages than in the North Sea, while males seemed to mature at similar ages than in the North Sea and Mediterranean. It is impossible to identify where thornback rays exhibit larger length at maturity and infinity due to the dispersion between reported values. A southward, from the NEA toward the MED, decreasing pattern can be outlined for the growth rate, while values were found to be constant within each of these regions. No studies performed in the Bay of Biscay reported values for any of the analysed life)history traits (Table 4).

Blonde ray Based on the two studies in which the age at maturity was reported, blonde rays mature earlier and at smaller sizes in the Celtic Sea than the Mediterranean Sea. Female blonde rays matured at larger length in the Mediterranean than in the NEA (i.e. North Sea and Celtic Sea), while males length seemed to not vary between the mentioned regions. In average, in NEA waters, blonde rays seem to reach larger lengths at infinity compared to the MED. The large deviation between reported values for length at infinity in the NEA could represent similar length at infinity in both regions. Similarly, in average blonde rays of the NEA (i.e. Celtic Sea) grow faster than rays of MED. Individuals of Portuguese water grow at a similar rate than in the Mediterranean sea. No values were found for the English Channel and Bay of Biscay despite being areas of its natural distribution (Table 5).

Spotted ray Spotted rays of both sexes were found to reach maturity at earlier ages and smaller lengths in the Celtic Sea than in the North Sea. No distinguishable pattern can be recognize for length at infinity between sub-regions of the NEA. Values from all sub-regions were found to be within the same range. However, in Portuguese waters, blonde rays appear to grow slightly faster, exhibiting smaller 
Table 8 Cross-study average (standard deviation) life-history trait values for cuckoo ray (Leucoraja naevus) in the NEA and subregions (North Sea, Celtic Sea, English Channel, Bay of Biscay, Portuguese waters) Sources: See Supplementary Table 1

\begin{tabular}{|c|c|c|c|c|c|c|c|c|c|}
\hline Region/sub-regions & $\operatorname{Agem}_{+}$ & Agem $\widehat{\jmath}$ & $\mathrm{Lm}_{+}$ & 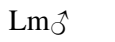 & $\mathrm{L} \infty$ 웅 & $\mathrm{L} \infty \widehat{\jmath}$ & $\mathrm{K}_{+}$ & $\mathrm{K} \widehat{\jmath}$ & Source \\
\hline Northeast Atlantic & $\begin{array}{l}5.8 \\
(2.25)\end{array}$ & $\begin{array}{l}5.5 \\
(1.87)\end{array}$ & $\begin{array}{l}56.2 \\
(2.65)\end{array}$ & $\begin{array}{l}54.2 \\
(2.95)\end{array}$ & $\begin{array}{r}81.97 \\
(8.52)\end{array}$ & $\begin{array}{l}75.9 \\
(10.89)\end{array}$ & $\begin{array}{l}0.17 \\
(0.048)\end{array}$ & $\begin{array}{l}0.26 \\
(0.102)\end{array}$ & - \\
\hline North Sea & 7.4 & 6.8 & $\begin{array}{l}54.4 \\
\quad(1.01)\end{array}$ & $\begin{array}{l}52.9 \\
\quad(2.93)\end{array}$ & 75.2 & 67.5 & 0.16 & 0.31 & 34,54 \\
\hline Celtic Sea & 4.3 & 4.1 & $58(2.54)$ & $\begin{array}{l}57.1 \\
\quad(0.35)\end{array}$ & $\begin{array}{l}82.9 \\
\quad(9.31)\end{array}$ & $\begin{array}{l}78.7 \\
\quad(11.44)\end{array}$ & $\begin{array}{l}0.17 \\
\quad(0.058)\end{array}$ & $\begin{array}{l}0.24 \\
\quad(0.0118)\end{array}$ & $18,21,54$ \\
\hline English Channel & - & - & - & - & - & - & - & - & - \\
\hline Bay of Biscay & - & - & - & - & - & - & - & - & - \\
\hline Portuguese waters & - & - & - & - & - & - & - & - & - \\
\hline $\begin{array}{l}\text { Mediterranean and } \\
\text { Black Sea }\end{array}$ & - & - & - & - & - & - & - & - & - \\
\hline
\end{tabular}

Values in bold represent the mean value for the region. Age $\mathrm{m}_{\mathrm{m}}$ Age at maturity; $\mathrm{L}_{\mathrm{m}}$ : Length at maturity; $\mathrm{L}_{\infty}$ : Length at infinity; K: Growth rate for males ( $\widehat{\zeta})$ and females ().

lengths at infinity than in northernmost sub-regions. Despite distributing in the English Channel, Bay of Biscay and Mediterranean Sea, no values for lifehistory traits were found from these sub-region (Table 6).

Undulate ray The undulate ray life-history traits have been mainly described in Portuguese waters, while only a few studies reported values for the length at maturity in the North Sea and Celtic Sea, English Channel and Bay of Biscay. From these studies, the length at maturity seemed to be constant across the northernmost sub-regions of NEA waters (i.e. North Sea and Celtic Sea, English Channel and Bay of Biscay), while rays from Portuguese water matured at smaller sizes. However the range of values reported in Portuguese water mean that this difference could be eliminated or shifted. The comparison for other parameters (i.e. age at maturity, length at infinity and growth rate) was not possible as they were only reported in Portuguese waters (Table 7).

Cuckoo ray Despite distributing toward in the English Channel, Bay of Biscay, Iberian Peninsula and even in the Mediterranean Sea, cuckoo rays life history trait values were only found to have been reported for the North Sea and Celtic Sea. Although reaching maturity at a younger age, Celtic Sea cuckoo ray were found to mature at larger sizes and reached larger lengths at infinity than in the North Sea. But, the strength of this tendency is again limited by the strong data dispersion in the reported values for both parameters. In both areas males matured faster than females and males matured faster in the North Sea (Table 8).

Starry ray Northerner starry rays studied in the northern North Sea and Skagerrak sub-regions were found to mature at larger sizes than individuals from

Table 9 Cross-study average (standard deviation) life-history trait values for starry skate (Amblyraja radiata) in different the NEA and sub-regions (North Sea and Skagerrak) Sources: See Supplementary Table 1

\begin{tabular}{|c|c|c|c|c|c|c|c|c|c|}
\hline Region/sub-regions & $\operatorname{Age}_{\mathrm{m}+}$ 운 & $\mathrm{Age}_{\mathrm{m}} \hat{\sigma}$ & $\mathrm{L}_{\mathrm{m}+}$ & $\mathrm{L}_{\mathrm{m}} \hat{\jmath}$ & $\mathrm{L}_{\infty}$ ? & $\mathrm{L}_{\infty} \hat{\mathrm{O}}$ & $\mathrm{K}_{+}$ & $\mathrm{K}_{\partial}$ & Source \\
\hline Northeast Atlantic & 5.6 & 5.3 & 40.6 & 39.9 & 69.2 & 65.3 & 0.16 & 0.195 & - \\
\hline North Sea/Skagerrak & - & - & 44.0 & 44.0 & - & - & - & - & 1 \\
\hline North Sea & 5.6 & 5.3 & 39.0 & 37.9 & 69.2 & 65.3 & 0.16 & 0.195 & $2,3,4,5$ \\
\hline
\end{tabular}

Values in bold represent the mean value for the region. $\mathrm{Age}_{\mathrm{m}}$ : Age at maturity; $\mathrm{L}_{\mathrm{m}}$ : Length at maturity; $\mathrm{L}_{\infty}$ : Length at infinity; $\mathrm{K}$ : Growth rate for males $(\hat{o})$ and females $(+)$. 
the North Sea. No other parameter was reported for other sub-regions. Values for the length at maturity and infinity seemed to be consistent in their values between different studies as shown by the relatively low standard deviation. Contrarily, a relatively high standard deviation was found between studies reporting the growth rate of starry rays in the North Sea (Table 9).

\section{Discussion}

This literature review of life-history traits of 14 batoid species of the NEA and the MED identified important information gaps for specific life-history traits parameters (e.g., lifespan and natural mortality) and certain skate species (sandy, shagreen and small-eyed ray). The PCA and cluster analysis hint at the presence of at least two groups of species that differ in their length at infinity $\left(\mathrm{L}_{\infty}\right)$, sizes $\left(\mathrm{L}_{\mathrm{m}}\right)$, age $\left(\mathrm{Age}_{\mathrm{m}}\right)$ at maturity and growth rate $(\mathrm{K})$, and to a lesser degree in their development rates and trophic level. The intraspecific analysis was severely limited to particular species and life-history traits, nonetheless it provides an important overview of the available data and data gaps. The detection of intraspecific patterns of variation between region and sub-regions is not possible at this level of data availability.

\section{Systematic literature review}

The natural abundance and density batoids in the NEA and MED impacts the quantity of available data on life-history traits for each species. In the North Sea the starry and thornback ray are caught frequently and in higher number in fisheries and scientific hauls compared to the less frequent and less abundant sandy, shagreen, and small-eyed rays, consequently increasing the number of studies performed on the species and values reported for life-history traits. Although the distribution range of the species and fishing/survey efforts will also impact the probability of encountering (e.g., fishing, sampling) a species in particular regions based (Froese and Pauly 2019) relevant data gaps were found in regions and sub-regions were a species is known to naturally distribute. Herein, even for some of the most data-available species, some areas of their distribution have not be analysed so far, to provide life-history traits values. For instance, the thornback ray, distributed from the North Sea to the Mediterranean Sea and Black Sea, however no life-history traits values were found from studies coming from the Bay of Biscay. This denotes the need of more focused research on batoids in both regions.

Together with the characteristics of their populations (i.e., misidentification may explain the lack of available data for the rare and less caught sandy, shagreen and small-eyed rays. Shagreen rays appear to have been mistakenly reported as white skate in the NEA (ICES 2020a, b, c) and as sandy ray in the MED (McCully and Walls 2015). Furthermore, sandy ray landings reported in Belgium are unreliable as they are suspected to refer to small-eyed rays (ICES 2020a, b, c). However, misidentification seems to not only be limited to rare species. For instance, blonde rays have been confused with spotted and speckled rays (Raja polystigma) in the Mediterranean Sea (Bertozzi et al. 2003), while spotted rays can be confused with blonde, thornback and cuckoo rays (Ellis et al. 2007) and even thornback rays have been confounded with starry rays (Williams 2007). Although misidentification may not be the sole cause of the lack of data for batoids in the NEA and MED, it reduces the already low quantity of available data for rare species, while simultaneously impacting the accuracy of the estimated parameters for all species involved.

While most life-history traits were found to be commonly reported, natural mortality and lifespan estimates were reported for only three and five of the species analysed in our study, respectively. Because these estimations require substantial amounts of data, they are difficult to calculate (Simpfendorfer et al. 2005). Furthermore, lifespan has commonly been estimated from in-captivity individuals which may or not represent its true value for wild individuals. Batoids stock assessments in the NEA and MED are made within the framework of data-limited stocks, and limited to survey catch rates indicators. The estimation of the natural mortality, together with size and age at maturity, are key traits to progress toward analytical population assessment models.

\section{Exploratory analysis}

Interspecific analysis Size is highly correlated with the onset of maturity in fish (Rochet 2000; Félix et al. 2011). Our review showed that larger batoids species 
(e.g., white skate and common skate complex) grow slower and reach maturity later and at larger sizes than smaller-sized, fast-growing species (e.g. cuckoo, spotted ray). Additionally, fish size and its growth rate are intrinsically linked to its metabolic rate. Slow metabolism species usually reach larger sizes as they do it a slower growth rate, while high metabolic species grow faster, but will be limited to smaller sizes due to the inherent limitations linked to higher metabolic activities (Clarke and Johnston 1999; Urbina and Glover 2013; Rosenfeld et al. 2015). In conclusion the two identified groups of batoids are very likely to be impacted in different ways by fishing (i.e. landings and discards), other sources of anthropogenic disturbance (i.e. habitat destruction, pollution) and environmental change (i.e. climate change).

Faster growth may be intrinsic to particular species, but is also usually related to higher metabolic rates when living in a warmer environment (Jobling 1993). Lower temperatures tend to limit the energy available for reproductive growth, as most energy is directed to ensure somatic growth (Ware 1980; Roff 1983), hence slowing down growth and delaying maturity. Water temperatures can therefore lead to an increase/reduction of the vulnerability of a species to perturbance. For instance, thornback and marbled electric ray have been found to register similar life-history traits. However, the generally colder water where the thornbacks are found (i.e. North Sea, Celtic Se) more frequently are very likely to impact on a different way the species and its resilience compared to the impact of warmer Mediterranean waters where on the latter species. Nonetheless, as it is for most fish species, although important, the temperature is not the only relevant parameter shaping life-history traits in batoids, but rather the whole ecological niche and evolutionary history which will dictate particular lifehistory traits and adaptations (Bijlsma and Loeschcke 2005; Schulte 2014).

The type of diet is also linked to the capacity to supply nutrients and energy, hence to grow at a faster or slower pace. Species that feed predominantly on sessile organisms tend to grow faster than ichthyophagous (Felix et al. 2011). The batoids analysed in this study vary from carnivores that feed on herbivores $(3.5 \leq \mathrm{TL}<4)$, such as sandy, shagreen and undulate ray, to carnivores that feed on other carnivores $(\mathrm{TL} \geq 4)$, such as common stingray, electric ray and white skate (e.g. Last et al. 2016, Froese and Pauly 2019). The trophic level value makes references to the diet of adult individuals, while juveniles are very unlikely to feed on the same prey. Herein, most batoids analysed in this study prey in fish when adults (e.g., common stingray, electric rays and white skate), but depend on benthic invertebrates during their growth and continue to do so even after reaching maturity (Ebert and Stehmann 2013). For instance, in the Adriatic Sea, small sized thornback rays $(<25 \mathrm{~cm} \mathrm{Lt})$ tended to feed primarily on small crustaceans, while larger specimens preferred to feed on larger decapods, cephalopods and teleost (Šantić et al. 2012). Such clear ontogeny dietary shifts have been detected for several batoids species during throughout their life cycle (e.g. Farias et al. 2006; Mulas et al. 2019; Brown-Vuillemin et al. 2020), complicating the usage of indicators, such as the trophic level, to compare species. Herein specific life-stage dietary preferences may represent different limitations and/or advantages when facing sources of disturbance.

Life-history strategies have been identified as the results of from trade-offs between different traits (Pecuchet et al. 2017). Batoid life-history traits tend to show an equilibrium strategy (Pecuchet et al. 2017) and are characteristic for species with relatively large body sizes, late maturation, low fecundity, long development times and high trophic levels, making them highly susceptible to be over-fished as their stocks need more time to recover. Although sharing a common life strategy, our study highlighted clear differences in the growth (length at infinity and growth rate) and reproductive (age and length at maturity) traits between batoids species of the NEA and MED making clear that all species may not be seen as equal in term of their vulnerability. These differences appear to follow the phylogeny of the studied species, as the genera Rostroraja and Dipturus were found to be outliers that distinguished themselves based on their larger sizes and slower growth rates. In contrast, species belonging to the genera Raja, Amblyraja, and Leucoraja share intermediate to smaller sizes, faster growth and attainment of maturity at smaller sizes and earlier ages. Grouping batoids species by genus has been suggested for management considerations, as they may share a similar susceptibility to individual (post-release survival) and population (overfishing) disturbances (STECF 2017). However, the identification of these groups should not be considered as strict 
rules on how to manage species, but rather as a species vulnerability gradient (Walker and Hislop 1998). For instance, although a member of the Raja genus, the blonde ray has been suggested to be more susceptible to overfishing due their particularly large length at infinity (Porcu et al. 2015), correlating to its position on the PCA biplot.

Slow-growing species, such as the common skate complex and white skate, reach maturity at later ages and will therefore take longer to reproduce and produce viable recruits, making the species less capable of recovering from intensive fishing and discard, and therefore easily overexploited (e.g. Ryland and Ajayi 1984; Dulvy 2002; Iglésias et al. 2010), justifying their protection status and fisheries ban in European waters (Council of the European Union 2019, 2020). Faster growing, early maturing and generally smaller size species (e.g. Raja, Lеисоraja) may be less sensitive (but not resilient, Pinsky et al. 2011) to fishing, as their populations tend to recover faster from exploitation, but face higher levels of stress when exposed to the air, due to their generally higher metabolic rates (Brown et al. 1993; Nilsson and Oslund-Nilsson 2008). Considering that all batoids species have been exempted from the landing obligation in European waters (Uhlmann et al. 2019; ICES 2020a, b, c), it is important to understand how lifehistory traits may relate to discard survival rates, and include these estimates into the calculation of fishing mortality (catches and discards) for stock assessments. Moreover, as survival studies are logistically complex, costly and long in duration, meaning that most species, life-history traits may provide a handy cost-effective proxy to identify species more/less likely to die once thrown back at the sea.

With few exemptions, batoids caught in European fisheries in the NEA are managed under a common TAC (ICES 2020a, b, c). The differences found between species are caused by differences in their growth and reproductive strategies, which is inherently linked to different degrees of vulnerability. This confirms the need for differential measures (i.e., TAC, maximum allowed by-catch, the prohibition of certain gear, gear selectivity, spatiotemporal avoidance) to apply for these species (as they currently exist). Reproductive traits, such as the length at maturity, are already being used to provide relevant information to continuously update minimum landings sizes. However, it is the subject of further research to conceptualize a way to include them into speciesspecific stock assessments. Incorporating a measure of the species vulnerability through the usage of lifehistory traits, such as the growth rate, could increase the realism of stock estimation and the model's predictive ability (Gislason et al. 2010; Le Quesne and Jennings 2012). Length-based indicators, such as the proportion of fish in the catch that are larger than length at maturity $\left(\mathrm{L}_{\mathrm{mat}}\right)$, have already been proposed to help stock assessment estimations of data-limited fisheries (e.g. Shephard et al. 2018). In conclusion, for batoids in the NEA and MED, life-history traits can and should be used as indicators and/or proxies while a robust data framework is still "on the making".

High definition data on life-history traits of batoids in the NEA and MED is very unlikely to be sampled, compiled and made available for researcher soon. Nonetheless, even when data on key parameters needed for stock assessment (age, growth, maturity) is absent, the correlation between life-history traits parameters could be used to identify proxies and indicators, hence providing a better understanding on the vulnerability of data-limited species (Dulvy and Reynolds 2002; Hutchings et al. 2012). For instance, when measures of length at maturity, used in stock assessment models and in the definition of management measures (i.e. minimum landing size), are not available for a particular species and/or region, measures of the highly correlated length at infinity could be used as proxy. This will also be highly valuable when looking to corroborate/validate historical parameter estimation based on old and now considered obsolete, ageing methods (Campana 2014).

Intraspecific analysis Plasticity in life-history traits across distribution ranges is common among elasmobranchs (e.g., Templeman 1987; LombardiCarlson et al. 2003; Neer and Thompson 2005; Licandeo and Cerna 2007; Bradley et al. 2017) and teleosts (e.g., Deniel 1990; Pauly 1994; Vinagre et al. 2009; Félix et al. 2011) and is generally attributed to environmental gradients (e.g. temperature, food sources) (Félix et al 2011) and anthropogenic disturbance (e.g. fisheries) (Devine et al. 2012; Claireaux et al. 2018) and is key to manage species stocks, as it can have important implications for stock assessment and management. Not being able to detect such variation can lead to relevant deviation in the 
estimation of stock dynamics, projections and reference points (Lorenzen 2016). Different batoids stocks have already been identified and are being used by the ICES to provide their advices (ICES 2021). The division and/or union of a species population into several fishing stock has to be made following the population structure of the species itself. However, this information is not always available, leading to questionable delimitations. Instead of building stock delimitations from fisheries patterns and characteristics, life-history traits can, in the absence of genetic and population dynamic studies, provide key understanding on the population structure of the species. For instance, the recompilation of life-history trait data could help to identify whether the stock delimited for cuckoo ray in the West of Scotland, southern Celtic Seas, western English Channel and Bay of Biscay (ICES 2020c) makes ecological sense, or like for most other species, if it should be split into smaller management units.

However for batoids in the NEA and MED the currently available data prevented us to analyse this. In addition to the lack of data from particular species, life-history traits and sub-regions, the differences in methodologies used in several decades of studies make straight forward comparisons impossible. Even when data is widely available (i.e. thornback ray), studies performed in the same sub-region were often found to deviate from each other. Although this differences may be caused by finer spatial plasticity (i.e. sea basins, gulfs) in batoids communities, it may also be the result of a the recompilation of a multitude of studies with non-homogeneous methodologies. Especially when comparing values between subregions in which the availability of data can be very different, average values have to be taken with care, as they will be influenced by a single low or high value in short series of data. Different sampling design (methodology per se, number of samples), year and season of the sampling, experience of the research team and the accuracy and precision of the reported parameters (i.e. standard deviation/error associated to the sample size) will also impact the quality of the obtained data.

Considering this, trying to explain why and how the registered values vary (or not) between regions and sub-regions would be prone to error and missinterpretation. For instance, the length at infinity values reported for the thornback ray in the Celtic Sea by Holden $\left(1972 ; \mathrm{L}_{\text {inf }}=63.3, \mathrm{~L}_{\text {inf }}{ }_{\widehat{O}} 49.5\right)$ are smaller than the average of the remaining reported values performed in this sub-region $\left(\mathrm{L}_{\text {inf } q}=120.1, \mathrm{~L}_{\text {inf } \widehat{\sigma}}\right.$ 103.1). However, there is no evidence to say that the former study and value, is less valid than the rest. Eliminating this value based solely on its deviation from the rest would therefore be wrong. We believe that valuing and assessing the (un) certainty of each reported estimations is beyond the scope of this study, and that this task, should be carried by a larger research team (i.e. ICES-WG). It is therefore beyond the possibilities of our study to accurately detect and identify general patterns of life-history traits plasticity across the studied area.

The compiled data revealed the presence of important regional data gaps for most of the analysed species. It is highly probable that this is due to the spatial limitation of scientific survey and sampling campaigns. Although, sampling batoids all across their distribution may be a complicated and costly task, obtaining a full picture of the variation of life-history trait across the species distribution is key to manage specific stocks. Hence we, as first priority, recommend to target future research to fulfil significant regional data gaps (i.e. Bay of Biscay and English Channel). It is also urgent to homogenize the methodologies for collecting and estimating life history parameters to facilitate multiple cross-study comparisons and the detection of general plasticity patterns in space and time. Finally, once an homogeneous picture of lifehistory traits is obtained for the studied area, the links between environmental (i.e. climate change) and anthropogenic factors (i.e. fisheries pressure) and trait plasticity could be established. This would provide a tool for sustainable management across different subregions and to predict how future scenarios will affect batoids fisheries stocks.

\section{Authors' contributions (optional: please review the submission guidelines from the journal whether statements are mandatory)}

DV, NVB, and SSU conceived the publication, DV, screened the literature, explored, analyzed the data, and made the figures under the supervision of NVB, SSU, and BA. DV wrote the manuscript, while PW, $\mathrm{NVB}, \mathrm{SSU}$, and $\mathrm{BH}$ provided critical additions and suggestions to the manuscript form and content. All 
authors edited the manuscript and agreed to its publication in its current form.

Acknowledgements Special thanks to the many scientists who indirectly contributed to this article through their reports and published studies. We would like to give special thanks to Els Torreele for her valuable advice, and to Marc Delaruelle for his time to proofread our manuscript. Finally, we very much appreciated the comments and suggestions of the anonymous reviewers and the editorial team of the journal. This study has received funding from the Interreg 2 Seas programme 2014-2020 co-funded by the European Regional Development Fund under subsidy contract No 2503-024 SUMARiS" (Sustainable Management of rays and skates).

Funding (Information that explains whether and by whom the research was supported) This study has received funding from the Interreg 2 Seas programme 2014-2020 co-funded by the European Regional Development Fund under subsidy contract No 2503-024 SUMARiS" (Sustainable Management of rays and skates).

Availability of data and material (data transparency) All data generated or analysed during this study are included in this published article and its supplementary information files.

\section{Declarations}

Conflict of interest (include appropriate disclosures) The authors have no conflicts of interest to declare that are relevant to the content of this article.

Human and animal participate No experiments and/or samples were taken from humans and/or animals throughout this study.

Consent to participate (include appropriate statements) All authors agreed to participate in the elaboration of this study.

Consent for publication (include appropriate statements) All authors edited the manuscript and agreed to its publication in its current form.

Open Access This article is licensed under a Creative Commons Attribution 4.0 International License, which permits use, sharing, adaptation, distribution and reproduction in any medium or format, as long as you give appropriate credit to the original author(s) and the source, provide a link to the Creative Commons licence, and indicate if changes were made. The images or other third party material in this article are included in the article's Creative Commons licence, unless indicated otherwise in a credit line to the material. If material is not included in the article's Creative Commons licence and your intended use is not permitted by statutory regulation or exceeds the permitted use, you will need to obtain permission directly from the copyright holder. To view a copy of this licence, visit http://creativecommons.org/licenses/by/4.0/.

\section{References}

Abdel-Aziz SH (1994) Observations on the biology of the common torpedo (Torpedo torpedo, Linnaeus, 1758) and marbled electric ray (torpedo marmorata, risso, 1810) from Egyptian Mediterranean waters. Mar Freshw Res 45:693-704. https://doi.org/10.1071/MF9940693

Basusta N, Gökhan K (2016) A study on age and growth of juvenile and semi adult Torpedo nobiliana Bonaparte, 1835 inhabiting Iskenderun Bay, northeastern Mediterranean Sea. Acta Biologica Turcica 29:143-149

Berestovskii EG (1994) Reproductive biology of skates of the family Rajidae in the seas of the Far North. J Ichthyol 34(6):26-37

von Bertalanffy L (1938) A quantitative theory of organic growth (inquiries on growth laws, II). Human Biol 10:181-213

Bertozzi M, Pasolini P, Hemida F, Capapé C \& Tinti F (2003) Species diversity in Algerian skates. Proceedings of the 7th European Elasmobranch Association Meeting: 38. San Marino

Beukhof E, Frelat R, Pecuchet L, Maureaud A, Dencker TS, Sólmundsson J, Punzón A, Primicerio R, Hidalgo M, Möllmann C, Lindegren M (2019) Marine fish traits follow fast-slow continuum across oceans. Sci Rep 9(1):17878. https://doi.org/10.1038/s41598-019-53998-2

Bielby J, Mace GM, Bininda-Emonds ORP, Cardillo M, Gittleman JL, Jones KE, Orme CDL, Purvis A (2007) The fastslow continuum in mammalian life history: an empirical reevaluation. Am Nat 169(6):748-757. https://doi.org/10. 1086/516847

Bijlsma R, Loeschcke V (2005) Environmental stress, adaptation and evolution: an overview. J Evolut Biol 18:744-749. https://doi.org/10.1111/j.1420-9101.2005.00962.x

Bradley D, Conklin E, Papastamatiou YP, McCauley DJ, Pollock K, Kendall BE, Gaines SD, Caselle JE (2017) Growth and life history variability of the grey reef shark (Carcharhinus amblyrhynchos) across its range. PLoS ONE 12(2):1-20. https://doi.org/10.1371/journal.pone.0172370

Brander K (1981) Disappearance of common skate Raia batis from Irish Sea. Nature 290:48-49. https://doi.org/10.1038/ 290048a0

Brander K, Palmer D (1985) Growth rate of Raia clavata in the Northeast Irish Sea. ICES J Mar Sci 42:125-128. https:// doi.org/10.1093/icesjms/42.2.125.

Brown JH, Marquet PA, Taper ML (1993) Evolution of body size: consequences of an energetic definition of fitness. Am Nat 142(4):573-584. https://doi.org/10.1086/285558

Brown-Vuillemin S, Barreau T, Caraguel JM, Iglésias SP (2020) Trophic ecology and ontogenetic diet shift of the blue skate (Dipturus cf. flossada). J Fish Biol 97(2):515-526

Camhi MD, Fowler SL, Musick JA, Bräutigam A, Fordham S, v \& Brautigam A (1998) Sharks and their relatives: ecology and conservation. In Survival. https://doi.org/10.1016/j. wear.2011.03.022

Campana SE (2014). Studies and reviews: age determination of elasmobranchs, with special reference to Mediterranean species: a technical manual (FAO, Ed.; Issue 94) 
Cannizzaro LG, Garofalo Rizzo LD, Gancitano S (1995) Raja clavata in the sicilian channel: growth, distribution, abundance. Biol Mar Mediterr 2:257-262

Capapé C (1976) Contribution à la biologie des Rajidae des côtes tunisiennes III. Raja clavata Linné, 1758: Répartition géographique et bathymétrique, sexualité reproduction et fécondité. Bull Du Muséum National D'histoire Naturelle 393:907-922

Capapé C, Guélorget O, Vergne Y, Quignard JP (2006) Biological observation on the black torpedo, Toperdo nobiliana Bonaparte 1835 (Chondrichthyes: Torpedinidae), from two Mediterranean areas. Annales, Series Historia Naturalis 16:19-28

Capapé C, Guélorget O, Vergne Y, Quignard JP (2007) Reproductive biology of the thornback ray Raja clavata (Chondrichthyes: Myliobatidae) from the coast of Languedoc (southern France, northern Mediterranean). Vie Et Milieu-Life and Environ 57(3):125-130

Catchpole T, Wright S, Bendall V, Hetherington S, Randall P, Ross E et al (2017) Ray discard survival - enhancing evidence of the discard survival of ray species. Lowestoft, UK, $\mathrm{p} 75$

Chen Y, Paloheimo JE (1994) Estimating fish length and age at $50 \%$ maturity using a logistic type model. Aquat Sci 56:206-219. https://doi.org/10.1007/BF00879965

Claireaux M, Jørgensen C, Enberg K (2018) Evolutionary effects of fishing gear on foraging behavior and life-history traits. Ecol Evol 8(22):10711-10721. https://doi.org/10. 1002/ece 3.4482

Clarke A, Johnston NM (1999) Scaling of metabolic rate with body mass and temperature in teleost fish. J Anim Ecol 68:893-905

Coelho R, Erzini K (2002) Age and growth of the undulate ray, Raja undulata, in the Algarve (southern Portugal). J Mar Biol Assoc UK 82(6):987-990. https://doi.org/10.1017/ S0025315402006495

Coelho R, Erzini K (2006) Reproductive aspects of the undulate ray, Raja undulata, from the south coast of Portugal. Fish Res 81(1):80-85. https://doi.org/10.1016/j.fishres.2006.05. 017

Commission of the European Union (2018). Commission delegated regulation (EU) 2018/2034 of 18 October 2018 establishing a discard plan for certain demersal fisheries in North-Wester waters for the period 2019-2020. Official Journal of the European Union L327, 8-16. Available at: https://eur-lex.europa.eu/legal-content/EN/TXT/?uri= CELEX\%3A32018R2034

Consalvo, I., Scacco, U., Romanelli, M., \& Vacchi, M. (2007). Comparative study on the reproductive biology of Torpedo torpedo (Linnaeus, 1758) and T. marmorata (Risso, 1810) in the central Mediterranean Sea. Scientia Marina, 71(2): 213-222. https://doi.org/10.3989/scimar.2007.71n2213

Cortés E, Arocha F, Beerkircher L, Carvalho F, Domingo A, Heupel M, Holtzhausen H, Santos MN, Ribera M, Simpfendorfer C (2010) Ecological risk assessment of pelagic sharks caught in Atlantic pelagic longline fisheries. Aquat Living Resour 23(1):25-34. https://doi.org/10.1051/ alr/2009044

Council of the European Union (2019). Regulation (EU) 2019/1241 of the European Parliament and of the Council 20 June 2019 on the conservation of fisheries resources and the protection of marine ecosystems through technical measures, amending Council Regulations (EC) No 1967/2006, (EC) No 122. Official Journal of the European Union L 198, 105-201. Available at: http://data.europa.eu/ eli/reg/2019/1241/oj

Council of the European Union (2020). COUNCIL REGULATION (EU) 2020/123 of 27 January 2020 fixing for 2020 the fishing opportunities for certain fish stocks and groups of fish stocks, applicable in Union waters and, for Union fishing vessels, in certain non-Union waters. Official Journal of the European Union L 25, 1-156. Available at: http://data.europa.eu/eli/reg/2020/123/oj.

Dalgleish HJ, Koons DN, Adler PB (2010) Can life-history traits predict the response of forb populations to changes in climate variability? J Ecol 98(1):209-217. https://doi.org/10. 1111/j.1365-2745.2009.01585.x

Demirhan SA, Engin S, Seyhan K, Akamca E (2005) Some biological aspects of thornback ray (Raja clavata L., 1758) in the Southeastern Black Sea. Turkish J Fish Aquat Sci $5(2): 75-83$

Deniel C (1990) Comparative study of growth of flatfishes on the west coast of Brittany. J Fish Biol 37:149-166. https:// doi.org/10.1111/j.1095-8649.1990.tb05936.x

Devine JA, Wright PJ, Pardoe HE, Heino M (2012) Comparing rates of contemporary evolution in life-history traits for exploited fish stocks. Can J Fish Aquat Sci 69(6):1105-1120. https://doi.org/10.1139/F2012-047

De Vries, Andrie \& Ripley, Brian D (2020). R package "ggdendro". Available from https://CRAN.R-project.org/ package $=$ ggdendro

Du Buit MH (1977) Age et croissance de Raja batis et de Raja naevus en Mer Celtique. ICES J Mar Sci 37:261-265. https://doi.org/10.1093/icesjms/37.3.261

Dulvy, N. K., Pasolini, P., Notarbartolo Di Sciara, G., Serena, F., Tinti, F., Ungaro, N., et al. (2006). Rostroraja alba, White skate. The IUCN Red List of Threatened Species e.T61408A1, pp. 1-11

Dulvy NK, Reynolds JD (2002) Predicting extinction vulnerability in skates. Conserv Biol 16(2):440-450. https://doi. org/10.1046/j.1523-1739.2002.00416.x

Duman OV, Basusta N (2013) Age and growth characteristics of marbled electric ray Torpedo marmorata (Risso, 1810) inhabiting Iskenderun Bay, North-eastern Mediterranean Sea. Turk J Fish Aquat Sci 13:881-896. https://doi.org/10. 4194/1303-2712-v13_3_19

Ebert DA, Stehmann MFW (2013) Sharks, batoids and chimaeras of the North Atlantic. In: FAO Species Catalogue for Fishery Purpouses No. 7 (FAO, Issue 7).

Ellis J, Ungaro N, Serena F, Dulvy N, Tinti F, Bertozzi M, Pasolini P, Mancusi C \& Noarbartolo di Sciara G (2007) Raja montagui. The IUCN Red List of Threatened Species 2007: e.T63146A12623141. https://doi.org/10.2305/ IUCN.UK.2007.RLTS.T63146A12623141.en

Ellis JR, McCully SR, Silva JF, Catchpole TL, Goldsmith D, Bendall V, \& Burt G (2012) Assessing discard mortality of commercially caught skates (Rajidae) - validation of experimental results. (MB5202). Final Report. March 2012. Departement for Environment Food \& Rural Affairs. Centre for Environment, Fisheries and Aquaculture Science (Cefas) 
Enever R, Catchpole TL, Ellis JR, Grant A (2009) The survival of skates (Rajidae) caught by demersal trawlers fishing in UK waters. Fish Res 97(1-2):72-76. https://doi.org/10. 1016/j.fishres.2009.01.001

Fahy E (1991) The South Eastern ray Raja spp. fishery, with observations on the growth of rays in Irish waters and their commercial grading. Irish Fish Investigat (series b) $37: 1-19$

FAO (2021) Identifiers for aquatic animals and plants. Available at: http://www.fao.org/cwp-on-fishery-statistics/ handbook/general-concepts/identifiers-for-aquaticanimals-and-plants/en/

Farias I, Figueiredo I, Moura T, Gordo LS, Neves A, SerraPereira B (2006) Diet comparison of four ray species (Raja clavata, Raja brachyura, Raja montagui and Leucoraja naevus) caught along the Portuguese continental shelf. Aquat Living Resour 19(2):105-114. https://doi.org/10. 1051/alr:2006010

Félix PM, Vinagre C, Cabral HN (2011) Life-history traits of flatfish in the Northeast Atlantic and Mediterranean Sea. J Appl Ichthyol 27(1):100-111. https://doi.org/10.1111/j. 1439-0426.2010.01623.x

Fennell H, Sciberras M, Hiddink JG, Kaiser MJ, Gilman E, Donnan D, Crawford R (2021) Exploring the relationship between static fishing gear, fishing effort, and benthic biodiversity: a systematic review protocol. Environ Evid 10(1):1-8. https://doi.org/10.1186/s13750-021-00242-y

Fitzmaurice P (1974). Size distribution and food of thornback rays (Raja clavata $\mathrm{L}$.) caught on rod and line on the Mayo coast. Irish Fisheries Investigations Series B, Department of Agriculture and Fisheries (Fisheries Division) 11B: pp. $1-18$

Frédou FL, Frédou T, Gaertner D, Kell L, Potier M, Bach P, Travassos P, Hazin F, Ménard F (2016) Life history traits and fishery patterns of teleosts caught by the tuna longline fishery in the South Atlantic and Indian Oceans. Fish Res 179:308-321. https://doi.org/10.1016/j.fishres.2016.03. 013

Froese, R. and D. Pauly. Editors. 2019. FishBase. World Wide Web electronic publication. www.fishbase.org, version (12/2019)

Fromentin JM, Fonteneau A (2001) Fishing effects and life history traits: a case study comparing tropical versus temperate tunas. Fish Res 53(2):133-150. https://doi.org/10. 1016/S0165-7836(00)00299-X

Gallagher MJ, Nolan CP, Jeal F (2005) Age, growth and maturity of the commercial ray species from the Irish Sea. J Northwest Atlantic Fish Sci. https://doi.org/10.2960/j. v35.m527

Gislason H, Daan N, Rice JC, Pope JG (2010) Size, growth, temperature and the natural mortality of marine fish. Fish Fisheries 11(2):149-158. https://doi.org/10.1111/j.14672979.2009.00350.x

Hobday AJ, Smith ADM, Stobutzki IC, Bulman C, Daley R, Dambacher JM, Deng RA, Dowdney J, Fuller M, Furlani D, Griffiths SP, Johnson D, Kenyon R, Knuckey IA, Ling SD, Pitcher R, Sainsbury KJ, Sporcic M, Smith T, Turnbull C, Walker, T;I., Wayte, S.E., Webb, H., Williams, A. \& Zhou, S. (2011) Ecological risk assessment for the effects of fishing. Fish Res 108(2-3):372-384. https://doi.org/10. 1016/j.fishres.2011.01.013
Hoenig J, Gruber S (1990) Life-history patterns in the elasmobranchs: implications for fisheries management. NOAA Tech Rep NMFS 90:1-16

Holden MJ (1975) The fecundity of Raja clavata in british waters. ICES J Mar Sci 36:110-118

Holden MJ, Rout DW, Humphreys CN (1971) The rate of egg laying by three species of ray. ICES J Mar Sci 33:335-339. https://doi.org/10.1093/icesjms/33.3.335

Holden MJ (1972) The growth rates of Raja brachyura, $R$. clavata and $R$. montagui as determined from tagging data. ICES J Marine Sci 34:161-168. https://doi.org/10.1093/ icesjms/34.2.161

ICES (2012) ICES Implementation of advice for data-limited stock in 2012 in its 2012 advice. ICES CM 2012/ACOM 68, https://doi.org/10.17895/ices.pub.5322.

ICES (2020a). Working Group on Elasmobranch Fishes (WGEF). ICES Scientific Reports/ Working Group on Elasmobranch Fishes (WEGF) https://doi.org/10.17895/ ices.pub. 7470

ICES (2020b). Cuckoo ray (Leucoraja naevus) in Division 9.a (Atlantic Iberian waters) ICES. ICES Advice on Fishing Opportunities, Catch, and Effort, pp. 1-4

ICES (2020c) Cuckoo ray (Leucoraja naevus) in subareas 6 and 7, and in divisions 8.a-b and 8.d (West of Scotland, southern Celtic Seas, and western English Channel, Bay of Biscay). ICES Advice on Fishing Opportunities, Catch, and Effort, pp. 1-4

ICES (2021) Working group on elasmobranch fishes (WEGF). ICES Sci Rep 3:59. https://doi.org/10.17895/ices.pub.8199

Iglésias SP, Toulhoat L, Sellos DY (2010) Taxonomic confusion and market mislabelling of threatened skates: Important consequences for their conservation status. Aquat Conserv Mar Freshwat Ecosyst 20(3):319-333. https://doi.org/10. $1002 /$ aqc. 1083

Ismen A (2003) Age, growth, reproduction and food of common stingray (Dasyatis pastinaca L., 1758) in İskenderun Bay, the eastern Mediterranean. Fish Res 60:169-176. https:// doi.org/10.1016/S0165-7836(02)00058-9

Jardas I (1973) A contribution to our knowledge of the biology and ecology of thornback ray (Raja clavata L.) and brown ray (Raja miraletus L.) in the Adriatic. Acta Adriat 15:1-43

Jobling M (1993) Bioenergetics: feed intake and energy partitioning," in Fish Ecophysiology, eds. J. C. Rankin and F. B. Jense (London: Chapman \& Hall), https://doi.org/10. 1007/978-94-011-2304-4_1

Juan-Jordá MJ, Mosqueira I, Freire J, Dulvy NK (2013) Life in 3-D: Life history strategies in tunas, mackerels and bonitos. Rev Fish Biol Fisheries 23(2):135-155. https://doi.org/10. 1007/s11160-012-9284-4

Kadri H, Marouani S, Bradai MN, Bouaïn A, Morize E (2014b) Age, growth, mortality, longevity and reproductive biology of the white skate, Rostroraja alba (Chondrichthyes: Rajidae) of the Gulf of Gabès (Southern Tunisia, Central Mediterranean). Turk J Fish Aquat Sci 14:193-204. https:// doi.org/10.4194/1303-2712-v14_1_21

Kadri H, Marouani S, Bradai MN, Bouaïn A, \& Morize E (2014a) Age, growth and length-weight relationship of the white skate, Rostroraja alba (Linnaeus, 1758) (Chondrichthyans: Rajidae), from the Gulf of Gabes (Tunisia, Central Mediterranean). J Coastal Life Med, 2(6): 
421-425. https://doi.org/10.12980/jclm.2.2014jclm-20140020

Kadri H, Marouani S, Saïdi B, Bradai MN, Bouaïn A, Morize E (2014c) Age, growth, sexual maturity and reproduction of the thornback ray, Raja clavata (L.), of the Gulf of Gabès (south-central Mediterranean Sea). Marine Biol Res 10(4):416-425. https://doi.org/10.1080/17451000.2013. 797584

Khan KS, Kunz R, Kleijnen J, Antes G (2003) Five steps to conducting a systematic review. J R Soc Med 96(3):118-121. https://doi.org/10.1258/jrsm.96.3.118

King JR, McFarlane GA (2003) Marine fish life history strategies: applications to fishery management. Fish Manage Ecol 10(4):249-264. https://doi.org/10.1046/j.1365-2400. 2003.00359.x

Kuparinen A, Mäntyniemi S, Hutchings JA, Kuikka S (2012) Increasing biological realism of fisheries stock assessment: towards hierarchical Bayesian methods. Environ Rev 20(2):135-151. https://doi.org/10.1139/a2012-006

Lart W (2019) Guide to Data-limited stock assessment (Issue July). SR744. Sea Fish Industry Authority.

Last P, Seret B, Stehmann M, White W, Carvalho Naylor G (2016). Rays of the World. eds. Last, P., Seret, B., Stehmann, M., White, W., Carvalho, Naylor. Comstock. CSIRO Publishing, Comstock Publishing Associates. p. 790

Le Quesne WJF, Jennings S (2012) Predicting species vulnerability with minimal data to support rapid risk assessment of fishing impacts on biodiversity. $\mathrm{J}$ Appl Ecol 49(1):20-28. https://doi.org/10.1111/j.1365-2664.2011. 02087.x

Licandeo R, Cerna FT (2007) Geographic variation in life-history traits of the endemic kite skate Dipturus chilensis (Batoidea: Rajidae), along its distribution in the fjords and channels of southern Chile. J Fish Biol 71:421-440. https:// doi.org/10.1111/j.1095-8649.2007.01499.x

Lombardi-Carlson LA, Cortés E, Parsons GR, Manire CA (2003) Latitudinal variation in life-history traits of bonnethead sharks, Sphyrna tiburo, (Carcharhiniformes:Sphyrnidae) from the eastern Gulf of Mexico. Mar Freshw Res 54:875-883. https://doi.org/10.1071/MF03023

Lorenzen K (2016) Toward a new paradigm for growth modelling in fisheries stock assessments: Embracing plasticity and its consequences. Fish Res 180:4-22. https://doi.org/ 10.1016/j.fishres.2016.01.006

MacArthur RH, Wilson EO (1967) The theory of island biogeography. Princeton University Press

McCully S, Scott F, Ellis JR (2012) Lengths at maturity and conversion factors for skates (Rajidae) around the British Isles, with an analysis of data in the literature. ICES J Mar Sci 69(10):1812-1822. https://doi.org/10.1093/icesjms/ fss 150

McCully, S., \& Walls, R. (2015). Leucoraja fullonica. IUCN Red List of Threatened Species, e.T161461A. https://doi. org/10.2305/IUCN.UK.2015-

1.RLTS.T161461A48938639.en

Mellinger J (1971) Croissance et reproduction de la torpille. III. L'appareil génital femelle11. Bull Biol Fr Belg 108:107-150
Michael SW (1993). Reef sharks and rays of the world. A guide to their identification, behaviour, and ecology. VI. Monterey, California: Sea Challengers. p. 107

Moss, Jordan Singh (2020). Assessing the performance of ICES elasmobranch harvest control rules through management strategy evaluation: the data-limited case of Raja clavata in the north sea. Thesis dissertation of the Master of Science in Marine Biological Resources (IMBRSea), University of Ghent, Ghent, Belgium

Moura T, Figueiredo I, Farias I, Serra-Pereira B, Coelho R, Erzini K, Neves A, Gordo LS (2007) The use of caudal thorns for ageing Raja undulata from the Portuguese continental shelf, with comments on its reproductive cycle. Mar Freshw Res 58(11):983-992. https://doi.org/10.1071/ MF07042

Mulas A, Bellodi A, Cannas R, Carbonara P, Cau A, Marongiu MF, Pesci P, Porcu C, Follesa MC (2019) Resource partitioning among sympatric elasmobranchs in the centralwestern Mediterranean continental shelf. Mar Biol 166(12):1-16. https://doi.org/10.1007/s00227-019-3607-0

Neer JA, Thompson BA (2005) Life history of the cownose ray, Rhinoptera bonasus, in the northern Gulf of Mexico, with comments on geographic variability in life history traits. Environ Biol Fish 73:321-331. https://doi.org/10.1007/ s10641-005-2136-5

Nichols AJD, Conley W, Batt B, Tipton AR (1976) Temporally dynamic reproductive strategies and the concept of R- and K-selection. Am Nat 110(976):995-1005

Nilsson GE, Östlund-Nilsson S (2008) Does size matter for hypoxia tolerance in fish? Biol Rev 83(2):173-189. https:// doi.org/10.1111/j.1469-185X.2008.00038.x

Notarbartolo Di Sciara G, Serena F, Ungaro N, Ferretti F, Pheeha S, \& Human B (2009) Torpedo marmorata, Spotted Torpedo. The IUCN Red List of Threatened Species, e.T161328A, pp. 1-9

Nottage AS, Perkins EJ (1983) Growth and maturation of roker Raja clavata L in the Solway Firth. J Fish Biol 23(1):43-48. https://doi.org/10.1111/j.1095-8649.1983.tb02880.x

Öckinger E, Schweiger O, Crist TO, Debinski DM, Krauss J, Kuussaari M, Petersen JD, Pöyry J, Settele J, Summerville KS, Bommarco R (2010) Life-history traits predict species responses to habitat area and isolation: a cross-continental synthesis. Ecol Lett 13(8):969-979. https://doi.org/10. 1111/j.1461-0248.2010.01487.x

Pascual M, Rives B, Schunter C, \& MaCpherson E (2017) Impact of life history traits on gene flow: a multispecies systematic review across oceanographic barriers in the Mediterranean Sea. PLoS ONE, 12(5), 1-20. https://doi. org/10.1371/journal.pone.0176419Klaas, Sys. (2020). Life-history traits of the thornback ray in the Eastern English Channel and North Sea. Unpublished raw data and analysis.

Patrick WS, Spencer P, Link J, Cope J, Field J, Kobayashi D, Lawson P, Gedamke T, Cortés E, Ormseth O, Bigelow K, Overholtz W (2010) Using productivity and susceptibility indices to assess the vulnerability of united states fish stocks to overfishing. Fish Bull 108(3):305-322

Pauly D (1994) A framework for latitudinal comparisons of flatfish recruitment. Neth J Sea Res 32:107-118. https:// doi.org/10.1016/0077-7579(94)90035-3 
Pecuchet L, Lindegren M, Hidalgo M, Delgado M, Esteban A, Fock HO, Gil de Sola L, Punzón A, Sólmundsson J, Payne MR (2017) From traits to life-history strategies: Deconstructing fish community composition across European seas. Glob Ecol Biogeogr 26(7):812-822. https://doi.org/ 10.1111/geb. 12587

Pinsky ML, Jensen OP, Ricard D, Palumbi SR (2011) Unexpected patterns of fisheries collapse in the world's oceans. Proc Nat Acad Sci 108(20):8317-8322. https://doi.org/10. 1073/pnas. 1015313108

Porcu C, Bellodi A, Cannas R, Marongiu MF, Mulas A, Follesa MC (2015) Life-history traits of the commercial blonde ray, Raja brachyura, from the central-western Mediterranean Sea. Mediterranean Marine Sci 16(1):90-102

R Core Team. R (2020) A Language and Environment for Statistical Computing. https://www.R-project.org

Rochet MJ (2000) A comparative approach to life-history strategies and tactics among four orders of teleost fish. ICES J Mar Sci 57:228-239. https://doi.org/10.1006/jmsc. 2000.0641

Roff DA (1983) An allocation model of growth and reproduction in fish. Can J Fish Aquat Sci 40:1395-1404. https:// doi.org/10.1139/f83-161

Rosenfeld J, van Leeuwen T, Richards J, Allen D (2015) Relationship between growth and standard metabolic rate: Measurement artefacts and implications for habitat use and life-history adaptation in salmonids. J Anim Ecol 84:4-20. https://doi.org/10.1111/1365-2656.12260

Ryland JS, Ajayi TO (1984) Growth and population dynamics of three Raja species (Batoidei) in Carmarthen Bay, British Isles. ICES J Mar Sci 41(2):111-120. https://doi.org/10. 1093/icesjms/41.2.111

Šantić M, Rada B, Pallaoro A (2012) Diet and feeding strategy of thornback ray Raja clavata. J Fish Biol 81(3):1070-1084. https://doi.org/10.1111/j.1095-8649. 2012.03382.x

Schnute JT, Richards LJ (1990) A unified approach to the analysis of fish growth, maturity, and survivorship data. Can J Fish Aquat Sci 47(1):24-40. https://doi.org/10.1139/ f90-003

Schulte PM (2014) What is environmental stress? Insights from fish living in a variable environment. J Exp Biol 2017:23-34

Serena F, Mancusi C, Morey G, \& Ellis JR (2009) Dasyatis pastinaca, Common Stingray. The IUCN Red List of Threatened Species, 8235(e.T161453A5427586), pp. 1-9

Serra-Pereira B, Figueiredo I, Farias I, Moura T, Gordo LS (2008) Description of dermal denticles from the caudal region of Raja clavata and their use for the estimation of age and growth. ICES J Mar Sci 65(9):1701-1709. https:// doi.org/10.1093/icesjms/fsn167

Serra-Pereira B, Figueiredo I, Gordo LS (2011a) Maturation, fecundity, and spawning strategy of the thornback ray, Raja clavata: Do reproductive characteristics vary regionally? Mar Biol 158:2187-2197. https://doi.org/10. 1007/s00227-011-1723-6

Serra-Pereira B, Figueiredo I, Gordo LS (2011b) Maturation, fecundity, and spawning strategy of the thornback ray, Raja clavata: do reproductive characteristics vary regionally? Mar Biol 158(10):2187-2197. https://doi.org/10. 1007/s00227-011-1723-6
Serra-Pereira B, Erzini K, Figueiredo I (2015) Using biological variables and reproductive strategy of the undulate ray Raja undulata to evaluate productivity and susceptibility to exploitation. J Fish Biol 86:1471-1490. https://doi.org/10. 1111/jfb.12653

Serra-Pereira B, Figueiredo I, Bordalo-Mochado P, Farias I, Moura T, \& Gordo LS (2005a) Age and growth of Raja clavata Linnaeus, 1758 - evaluation of ageing precision using different types of caudal denticles. ICES Conference Meeting 2005/N:17, 17 (May 2016), pp. 1-10

Serra-Pereira B, Figueiredo I, Bordalo-Mochado P, Farias I, Moura T, Gordo LS (2005b) Description of Portuguese mixed-fisheries with positive landings of Raja brachyura Lafont, 1973 and Raja montagui Fowler, 1910. ICES Conference Meeting 2005/N:18, 18, pp. 1-10

Shephard S, Davidson I, Walker A, Gargan P (2018) Lengthbased indicators and reference points for assessing datapoor stocks of diadromous trout Salmo trutta. Fish Res 199:36-43. https://doi.org/10.1016/j.fishres.2017.11.024

Šifner KS, Vrgoč N, Dadić V, Isajlović I, Peharda M, Piccinetti C (2009) Long-term changes in distribution and demographic composition of thornback ray, Raja clavata, in the northern and central Adriatic Sea. J Appl Ichthyol 25(SUPPL. 1):40-46. https://doi.org/10.1111/j.1439-0426. 2008.01204.x

Simpfendorfer CA, Bonfil R, Latour RJ (2005) Mortality estimation. In: Management techniques in elasmobranch fisheries. FAO Fisheries Paper. Vol. 5, p. 474.

Skjæraasen JE, Bergstad OA (2000) Distribution and feeding ecology of Raja radiata in the northeastern North Sea and Skagerrak (Norwegian Deep). ICES J Mar Sci 57(4):1249-1260. https://doi.org/10.1006/jmsc.2000.0811

STECF (2017). Long-term management of skates and rays (STECF-17-21). Scientific Technical and Economic Committee for Fisheries (STECF) - Luxembourg. https:// doi.org/10.2760/44133

Stephan E, Gadenne H, Meheust E, Jung JL (2014) Projet RECOAM: étude de cinq espèces de raies présentes dans les eaux côtières d'Atlantique et de Manche.: Vol. Rapport fi. Association Pour l'Etude et la Conservation des Sélaciens et Laboratoire BioGeMME

Steven GA (1934) Observations on the growth of the claspers and cloaca in Raia clauata Linnaeus. J Mar Biol Assoc UK 19:887-899. https://doi.org/10.1017/S0025315400046841

Steven GA (1936) Migrations and growth of the thornback ray (Raia clavata L.). J Mar Biol Assoc UK 20:605-614. https://doi.org/10.1017/S0025315400058173

SUMARiS (2019) Vertebrae preparation protocol for age estimation of Raja clavata. Interreg 2 Seas programme. European Regional Development Fund

Templeman W (1987) Differences in sexual maturity and related (Raja radiata) in the Northwest Atlantic. J Northwest Atlantic Fish Sci 7:155-167

Shark Trust (2020) British Skates \& Ray ID Guide. Available at: https://www.sharktrust.org/Pages/FAQs/Category/skatesrays

Uhlmann SS, Ulrich C, Kennelly SJ (2019) The European landing obligation: Reducing discards in complex, multispecies and multi-jurisdictional fisheries (Uhlmann, S. S.; Ulrich, C. \& Kennelly, S. J. Eds.). Springer Nature. Cham, Switzerland. https://doi.org/10.1007/978-3-030-03308-8 
Urbina MA, Glover CN (2013) Relationship between fish size and metabolic rate in the oxyconforming Inanga galaxias maculatus reveals size-dependent strategies to withstand hypoxia. Physiol Biochem Zool 86:740-749. https://doi. org/10.1086/673727

Vinagre C, Ferreira T, Matos L, Costa MJ, Cabral HN (2009) Latitudinal gradients in growth and spawning of sea bass, Dicentrarchus labrax, and their relationship with temperature and photoperiod. Estuar Coast Shelf Sci 81:375-380. https://doi.org/10.1016/j.ecss.2008.11.015

Vinther M (1989) Some notes on the Biology of the starry ray Raja radiata, in the North Sea. ICES Working document for ICES study group on Elasmobranch fisheries, April 1989:1-20

Walker PA, Hislop JR (1998) Sensitive skates or resilient rays? Spatial and temporal shifts in ray species composition in the central and north-western North Sea between 1930 and the present day. Journal of Materials Science, 55, 392-402.Walker, P. A. (1999). Fleeting images dynamics of North Sea ray. PhD. dissertation thesis, University of Amsterdam, Amsterdam, Holland. Retrieved from: https:// hdl.handle.net/11245/1.162676

Walker ND, Bird C, Ribeiro Santos A, McCully Phillips SR, Ellis JR (2018) Length -based indicator to assess the status of skates (Rajidea). In: Working Documents to the ICES Working Groups on Elasmobranches Fishes. Lisbon. 19-28 June 2018

Walsh SJ (1994) Life history traits and spawning characteristics in populations of long rough dab (American plaice)
Hippoglossoides platessoides (Fabricus) in the North Atlantic. Neth J Sea Res 32:241-254. https://doi.org/10. 1016/0077-7579(94)90002-7

Ware DM (1980) Bioenergetics of stock and recruitment. Can J Fish Aquat Sci 37:1012-1024. https://doi.org/10.1016/ 0198-0254(80)96091-4

Whittamore J, Mccarthy I (2005) The population biology of the thornback ray, Raja clavata in Caernarfon Bay, North Wales. J Mar Biol Assoc UK 85(5):1089-1094. https://doi. org/10.1017/S0025315405012130

Wie T, Simko, V (2017) R package "corrplot ": Visualization of a Correlation Matrix (Version 0.84). Available from https://github.com/taiyun/corrplot

Williams T (2007) Cartilaginous fishes along the North-Norwegian coast. Distributions and densities with regard to fishing and sea temperature. Master thesis in International Fisheries Management. Norwe- gian College of Fishery Science. University of Troms $\varnothing, 62$ pp., http://www.ub.uit. no/munin/han- dle/10037/975

Yigin CC, Ismen A (2012) Age, growth and reproduction of the common stingray, Dasyatis pastinaca from the North Aegean Sea. Mar Biol Res 8:644-653. https://doi.org/10. 1080/17451000.2012.659667

Publisher's Note Springer Nature remains neutral with regard to jurisdictional claims in published maps and institutional affiliations. 